\title{
Effects and Mechanisms of Tea for the Prevention and Management of Diabetes Mellitus and Diabetic Complications: An Updated Review
}

\author{
Jin-Ming Meng ${ }^{1}$, Shi-Yu Cao ${ }^{1}$, Xin-Lin Wei ${ }^{2}$, Ren-You Gan ${ }^{2, *}$,, Yuan-Feng Wang ${ }^{3}$, \\ Shu-Xian Cai ${ }^{4}$, Xiao-Yu Xu ${ }^{1}$, Pang-Zhen Zhang ${ }^{5}$ and Hua-Bin Li ${ }^{1, *(D)}$ \\ 1 Guangdong Provincial Key Laboratory of Food, Nutrition and Health, Department of Nutrition, School of \\ Public Health, Sun Yat-sen University, Guangzhou 510080, China; mengjm@mail2.sysu.edu.cn (J.-M.M.); \\ caoshy3@mail2.sysu.edu.cn (S.-Y.C.); xuxy53@mail2.sysu.edu.cn (X.-Y.X.) \\ 2 Department of Food Science \& Technology, School of Agriculture and Biology, Shanghai Jiao Tong University, \\ Shanghai 200240, China; weixinlin@sjtu.edu.cn \\ 3 College of Life Sciences, Shanghai Normal University, 100 Guilin Road, Shanghai 200234, China; \\ yfwang@shnu.edu.cn \\ 4 Key Laboratory of Ministry of Education for Tea Science, Hunan Agricultural University, Changsha 410128, \\ China; caishuxian@hunau.edu.cn \\ 5 School of Agriculture and Food, The University of Melbourne, Parkville, Victoria 3010, Australia; \\ pangzhen.zhang@unimelb.edu.au \\ * Correspondence: renyougan@sjtu.edu.cn (R.-Y.G.); lihuabin@mail.sysu.edu.cn (H.-B.L.); \\ Tel.: +86-21-3420-8517 (R.-Y.G.); +86-20-8733-2391 (H.-B.L.)
}

Received: 14 May 2019; Accepted: 6 June 2019; Published: 10 June 2019

\begin{abstract}
Diabetes mellitus has become a serious and growing public health concern. It has high morbidity and mortality because of its complications, such as diabetic nephropathy, diabetic cardiovascular complication, diabetic neuropathy, diabetic retinopathy, and diabetic hepatopathy. Epidemiological studies revealed that the consumption of tea was inversely associated with the risk of diabetes mellitus and its complications. Experimental studies demonstrated that tea had protective effects against diabetes mellitus and its complications via several possible mechanisms, including enhancing insulin action, ameliorating insulin resistance, activating insulin signaling pathway, protecting islet $\beta$-cells, scavenging free radicals, and decreasing inflammation. Moreover, clinical trials also confirmed that tea intervention is effective in patients with diabetes mellitus and its complications. Therefore, in order to highlight the importance of tea in the prevention and management of diabetes mellitus and its complications, this article summarizes and discusses the effects of tea against diabetes mellitus and its complications based on the findings from epidemiological, experimental, and clinical studies, with the special attention paid to the mechanisms of action.
\end{abstract}

Keywords: tea; polyphenol; epigallocatechin-3-gallate; diabetes mellitus; complication; mechanisms

\section{Introduction}

Diabetes mellitus, one of the most common metabolic disorders in the world, is featured by hyperglycemia caused by either decreased insulin secretion or insulin resistance [1]. The incidence of diabetes mellitus in adults has been increasing in the last decades [2,3]. Diabetes mellitus has been the fifth leading cause of death in the world, and the International Diabetes Mellitus Federation predicted that 592 million people worldwide will suffer from diabetes mellitus by the year 2035 [4]. Numerous studies have demonstrated that diabetes mellitus, especially type 2 diabetes mellitus (T2DM), could induce diverse complications, such as diabetic nephropathy, diabetic cardiovascular 
complications, neuropathy, eye, and liver complications, which have been the major causes of its morbidity and mortality [4,5]. Therefore, it is necessary and urgent to find effective strategies for the prevention and management of diabetes mellitus and its complications [6].

As a popular drink worldwide, tea has many bioactivities and healthy benefits, such as antioxidant, anticancer, hepatoprotective, cardioprotective, anti-obesity, improving intestinal flora, and antidiabetic effects [7-14]. Due to the different characteristics and fermentation degrees caused by various manufacturing processes, tea can be classified into six main categories, including unfermented green tea, slightly fermented white tea, partly fermented yellow tea, semi-fermented oolong tea, fully fermented black tea, and post-fermented dark tea $[15,16]$. Moreover, tea contains many bioactive components, especially polyphenols, such as catechins (Figure 1), flavonols, theaflavins, and thearubigins, which have the potential to decrease the risk of diabetes mellitus and its complications [17].<smiles>C[C@H]1Oc2cc(O)cc(O)c2C[C@@]1(C)Cc1ccc(O)c(O)c1</smiles>

(-)-epigallocatechin<smiles>O=C(O[C@H](c1cc(O)c(O)c(O)c1)[C@H]1CCc2c(O)cc(O)cc2O1)c1cc(O)c(O)c(O)c1</smiles>

(-)-epigallocatechin-3-gallate<smiles>O=C(O[C@H]1Cc2c(O)cc(O)cc2O[C@H]1c1cc(O)c(O)c(O)c1)c1cc(O)c(O)c(O)c1</smiles>

(-)-gallocatechin gallate<smiles>[CH][C@H]1[C@@H](OC(=O)c2cc(O)c(O)c(O)c2)CCc2c(O)cc(O)cc2O[C@H]1c1ccc(O)c(O)c1</smiles>

(-)-epicatechin-3-gallate

Figure 1. Chemical structures of main catechins in tea.

The effects of tea against diabetes mellitus and its complications have been widely studied. Epidemiological research found that the consumption of tea was negatively associated with the risk of diabetes mellitus and its complications $[18,19]$. Further, recent in vitro, in vivo, and clinical trials further supported the effects of tea on the prevention and treatment of diabetes mellitus and its complications [20,21]. In addition, tea is a potential hypoglycemic substance with low cost, good patient compliance, and fewer side effects compared with many synthetic hypoglycemic drugs [22]. In order to provide an updated understanding of tea targeting diabetes mellitus and its complications, we searched related literature of epidemiological, experimental, and clinical studies based on PubMed and Web of Science databases and reviewed and discussed the protective effects of tea against diabetes mellitus and its complications, highlighting the related molecular mechanisms.

\section{Epidemiological Investigations}

Concerning the wide consumption of tea, a number of epidemiological studies have evaluated the effects of tea on diabetes mellitus and its complications.

Several cohort studies have estimated the effects of tea on diabetes mellitus. A cohort study pointed out that the consumption of tea showed protective effects against T2DM ( $R R=0.55,95 \%$ CI $(0.55,1.08))$ for Vietnamese adults [23]. Another prospective cohort study revealed a negative relationship between the risk of diabetes mellitus and the consumption of tea ( $\mathrm{HR}=0.77,95 \% \mathrm{CI}$ 
$(0.59,1.00))$ for subjects aged less than 60 years old in the United States [24]. It was also reported that tea intake was negatively associated with diabetes mellitus ( $\mathrm{HR}=0.66,95 \% \mathrm{CI}(0.61,1.22)$ in British subjects [25]. In addition, a prospective cohort study demonstrated an inverse association between green tea intake and the risk of diabetes mellitus ( $p$-trend $=0.02$ ) only for women in the Japanese population [26]. Furthermore, the Singapore Chinese health prospective study found that more than one cup of black tea per day could reduce the risk of diabetes mellitus by $14 \%(\mathrm{RR}=0.86,95 \% \mathrm{CI}$ $(0.74,1.00))$ [27]. A retrospective cohort study found that green tea was inversely associated with T2DM $(\mathrm{OR}=0.67,95 \% \mathrm{Cl}(0.47,0.94))$, while black tea and oolong tea showed no significant effects for Japanese adults [28]. For black tea, the reasons of inconsistent results may be related to the differences of dose and frequency of consumption as well as research subjects $[27,28]$.

Some case-control studies also have evaluated the effects of tea on diabetes mellitus. For instances, a case-control study found that tea could reduce the risk of T2DM (OR $=0.66,95 \% \mathrm{Cl}(0.49,0.89))$ for Vietnamese adults [29]. Another case-control study revealed that long-term drinking of green tea had preventive effects on diabetic retinopathy $(\mathrm{OR}=0.49,95 \% \mathrm{CI}(0.26-0.90))$, and people who regularly drink green tea had a 50\% lower risk of developing diabetic retinopathy than those who don't drink green tea in China [30]. A population-based case-control study in Shantou, China found that long-term consumption of oolong tea could reduce the risk of hypercholesterolemia and triglycerides $(\mathrm{OR}=0.10$, 95\% CI (0.06-0.16)) in southern China [31]. Additionally, one descriptive study revealed that long-term tea intake had negative relation with T2DM in Cyprus [32].

Moreover, several meta-analyses also supported the protective effects of tea consumption against diabetes mellitus. These meta-analyses included cohort studies conducted in different countries, such as America, China, Japan, and South Korea, and involved subjects of different races, genders, and ages. It was found that tea could increase the fasting blood insulin level $(1.30 \mathrm{U} / \mathrm{L}, 95 \% \mathrm{CI}$ $(0.36-2.24)$ ) [6], and tea consumption $\geq$ four cups per day could reduce the risk of T2DM $(R R=0.8$, 95\% CI $(0.7,0.93))$ [18]. Further, another meta-analysis revealed that three to four cups of tea per day had an approximately $20 \%$ lower risk of diabetes mellitus than no tea per day $(\mathrm{RR}=0.82,95 \% \mathrm{CI}(0.73$, 0.94)) [33]. In addition, a meta-analysis including sixteen cohorts revealed a significant linear and inverse association between tea consumption and the risk of T2DM ( $p=0.02)$ [34], and it was also found that more than three cups of tea per day is beneficial for the prevention of T2DM $(\mathrm{RR}=0.84$, $95 \%$ CI $(0.73,0.97)$ [35].

However, there are also some inconsistent results in epidemiological investigations. For instance, a prospective cohort study reported that the consumption of tea was not associated with T2DM [19]. In addition, compared with those not consuming oolong tea, multivariable adjusted hazard ratios (HR) for developing diabetes mellitus were 1.64 (95\% CI (1.11-2.40)) for those drinking two or more cups of oolong per day [36]. The reasons of negative findings may be due to different sensitivities of different ethnic groups to tea, differences of tea composition in different regions, and bad control of drinking time and dose. Further, green tea was found no effects on T2DM in two meta-analysis [37,38], which may be related to the quality of the included studies, the level of evidence, and the size of the sample.

In summary, many epidemiological evidences have supported the efficiency of tea consumption against diabetes mellitus and its complications (Table 1), although inconsistent findings also exist. In addition, studies are still lacking concerning about the association between tea and diabetic complications, which should be further investigated in the future. 
Table 1. The relationship of tea consumption and diabetes mellitus by epidemiological studies.

\begin{tabular}{|c|c|c|c|c|c|c|}
\hline Diseases & Tea Type & Study Type & Participants & Dose & Results & Ref. \\
\hline Diabetes mellitus & Tea & $\begin{array}{l}\text { Prospective cohort } \\
\text { study }\end{array}$ & $\begin{array}{l}\text { Individuals }(\mathrm{N}=7006) \text { aged } 32-88 \text { without } \\
\text { diabetes mellitus }\end{array}$ & N/A & $\begin{array}{l}\text { The consumption of tea showed an decreased risk of diabetes mellitus for } \\
\text { nonelderly adults who had previously lost weight. }\end{array}$ & [24] \\
\hline Diabetes mellitus & Green tea & Cohort study & Elderly Japanese men and women $(\mathrm{N}=11,717)$ & N/A & Women with a higher intake of green tea had a lower risk of diabetes mellitus. & [26] \\
\hline Diabetes mellitus & Black Tea & $\begin{array}{l}\text { placebo-controlled } \\
\text { study }\end{array}$ & Total participants $(\mathrm{N}=24)$ aged $20-60$ & N/A & Drinking black tea could decrease postprandial blood sugar. & [39] \\
\hline T2DM & Tea & $\begin{array}{l}\text { Population-based } \\
\text { cohort study }\end{array}$ & $\begin{array}{l}\text { Danish non-diabetic women with singleton } \\
\text { pregnancies }(N=71,239)\end{array}$ & $\begin{array}{l}8 \text { cups } \\
\text { per day }\end{array}$ & $\begin{array}{l}\text { The consumption of tea showed protective effects against T2DM }(\mathrm{RR}=0.55 \text {, } \\
95 \% \mathrm{CI}(0.55,1.08)) .\end{array}$ & [23] \\
\hline T2DM & Tea & $\begin{array}{l}\text { Prospective Cohort } \\
\text { study. }\end{array}$ & African American women $(\mathrm{N}=46,906)$ & N/A & The consumption of tea wasn't associated with T2DM. & [19] \\
\hline T2DM & Tea & $\begin{array}{l}\text { Prospective cohort } \\
\text { study. }\end{array}$ & British men (N = 4055) and women ( $N=1768)$ & N/A & Tea intake was beneficial for DM $(\mathrm{HR}=0.66,95 \% \mathrm{CI}(0.61,1.22)), p<0.05$ & [25] \\
\hline T2DM & Tea & Case-Control study & $\begin{array}{l}\text { Newly diagnosed diabetic cases }(\mathrm{N}=599) \\
\text { Hospital-based controls }(\mathrm{N}=599)\end{array}$ & $\begin{array}{l}2 \text { cups } \\
\text { per day }\end{array}$ & $\begin{array}{l}\text { Habitual drinking tea could reduce the risk of T2DM } \\
(\mathrm{OR}=0.66,95 \% \mathrm{CI}(0.49-0.89)) .\end{array}$ & [29] \\
\hline T2DM & Tea & Case-Cohort Study & Total participants $(\mathrm{N}=16,835)$ & $\begin{array}{l}\geq 1 \text { cups } \\
\text { per day }\end{array}$ & $\begin{array}{c}\text { The consumption of tea has negative relation with T2DM } \\
1 \text { cup/day }(\mathrm{HR}=0.84,95 \% \mathrm{CI}(0.71,1.00)) \\
\geq 2 \text { cups/day }(\mathrm{HR}=0.93,95 \% \mathrm{CI}(0.81,1.05))\end{array}$ & [40] \\
\hline T2DM & Tea & Meta-analysis & $\begin{array}{l}\text { Total participants }(\mathrm{N}=545,517) \\
\text { Cases with T2DM }(\mathrm{N}=37,445)\end{array}$ & N/A & The consumption of tea has negative relation with T2DM $(p=0.02)$. & [34] \\
\hline T2DM & Tea & Meta-analysis & N/A & N/A & $\begin{array}{l}\text { Drinking tea daily ( } \geq 3 \text { cups/day) is associated with a lower risk of T2DM } \\
(\mathrm{RR}=0.84,95 \% \mathrm{CI}(0.73,0.97))\end{array}$ & [35] \\
\hline T2DM & Tea & Meta-analysis & $\begin{array}{l}\text { Total participants }(\mathrm{N}=324,141) \text {; } \\
\text { Cases with T2DM }(\mathrm{N}=11,400)\end{array}$ & N/A & Tea consumption a $\geq 4$ cups per day may lower the risk of T2DM. & [18] \\
\hline T2DM & Tea & Meta-analysis & Total participants $(\mathrm{N}=457,922)$ & N/A & The consumption of tea was associated with reduced risk of diabetes mellitus. & [33] \\
\hline T2DM & Tea & Descriptive study & Total participants $(\mathrm{N}=940)$ & N/A & $\begin{array}{l}\begin{array}{l}\text { Long-term tea intake had effects on the prevention and treatment of diabetes } \\
\text { mellitus. }\end{array}\end{array}$ & [32] \\
\hline T2DM & Green tea & Meta-analysis & N/A & $\mathrm{N} / \mathrm{A}$ & The consumption of tea wasn't associated with T2DM. & [38] \\
\hline T2DM & Green tea & Meta-analysis & $\mathrm{N} / \mathrm{A}$ & N/A & $\begin{array}{l}\text { Tea or tea extract could maintain stable fasting insulin level in patients with } \\
\text { T2DM. }\end{array}$ & [6] \\
\hline T2DM & Green tea & Meta-analysis & Total participants $(\mathrm{N}=510)$ & $\mathrm{N} / \mathrm{A}$ & Green tea had no effect on insulin sensitivity and blood glucose control. & [37] \\
\hline T2DM & Black tea & Cohort study. & Total participants $(\mathrm{N}=36,908)$ & $\begin{array}{l}\geq 1 \text { cups } \\
\text { per day }\end{array}$ & Black tea had association with T2DM $(\mathrm{RR}=0.86,95 \% \mathrm{CI}(0.74,1.00))$. & [27] \\
\hline T2DM & Oolong tea & $\begin{array}{l}\text { Prospective cohort } \\
\text { study. }\end{array}$ & Japanese male workers $(\mathrm{N}=4975)$ & $\begin{array}{l}\geq 1 \text { cups } \\
\text { per day }\end{array}$ & $\begin{array}{c}\text { Long-term consumption of oolong tea may be a predictive factor for new } \\
\text { onset diabetes mellitus. } \\
1 \text { cup/day }(\mathrm{HR}=1.00,95 \% \mathrm{CI}(0.67-1.49)) \text {. } \\
\geq 2 \text { cups } / \text { day }(\mathrm{HR}=1.64,95 \% \mathrm{CI}(1.11-2.40))\end{array}$ & [36] \\
\hline Diabetic nephropathy & Green tea & Cohort study & Diabetic patients $(\mathrm{N}=42)$ & N/A & Green tea extract could reduce proteinuria in diabetic patients. & [41] \\
\hline Diabetic Retinopathy & Green tea & Case-Control Study & $\begin{array}{l}\text { Cases with diabetic retinopathy }(\mathrm{N}=100) \text { and } \\
\text { diabetic patients without retinopathy }(\mathrm{N}=100)\end{array}$ & N/A & $\begin{array}{l}\text { Long-term drinking green tea had preventive effects on diabetic retinopathy } \\
\qquad(\mathrm{OR}=0.49,95 \% \mathrm{CI}(0.26-0.90)) .\end{array}$ & [30] \\
\hline
\end{tabular}




\section{Experimental Studies}

The effects of tea on diabetes mellitus and its complications have been widely studied by in vitro and in vivo experimental studies, and the relative mechanisms of action have also been widely explored.

\subsection{Diabetes Mellitus}

\subsubsection{Type 1 Diabetes Mellitus (T1DM)}

T1DM is characterized by progressively destroyed pancreatic $\beta$-cells and reducing or no insulin secretion [17], accounting for 5-10\% diabetes mellitus [42]. Increasing studies have found the effects of tea against T1DM [43-45].

The main effective catechin of green tea is epigallocatechin gallate (EGCG) [46]. EGCG could protect the functions of pancreatic $\beta$-cells by inhibiting inflammatory factors and reducing reactive oxygen species (ROS) in vitro [47]. Further, EGCG could down-regulate the production of inducible nitric oxide synthase (iNOS) to protect pancreatic islet $\beta$-cells [48]. In addition, green tea was also found to reduce blood sugar level by promoting pancreatic $\beta$-cells to produce more insulin in diabetic mice [49]. Furthermore, dark tea containing gallic acid, a water-soluble ingredient, could promote skeletal muscle glucose transport in the absence of insulin by stimulating protein kinase B (Akt) phosphorylation [50].

\subsubsection{Type 2 Diabetes Mellitus (T2DM)}

T2DM is defined as insulin resistance in the target tissue and a relative lack of insulin secreted by islet $\beta$-cells [51], accounting for 90-95\% diabetes mellitus [42]. Increasing studies showed that tea was effective in preventing and managing T2DM [6]. Next, the molecular mechanisms of tea against T2DM are discussed according to the types of tea.

A type II arabinogalactan, 7WA, isolated from green tea, could increase glucose-stimulated insulin secretion through cyclic adenosine monophosphate-Akt (cAMP-Akt) pathway [44]. Additionally, green tea polyphenols, primarily EGCG, could activate the 5'-adenylic acid-activated protein kinase (AMPK) pathway to improve the closure of insulin stress signal pathway caused by phosphorylation of insulin receptor substrate-1 (IRS-1), finally ameliorating the insulin resistant status of human hepG2 hepatoma cells [52]. In addition, it was reported that supplement of green tea polyphenols could improve insulin sensitivity by upregulating the insulin signaling protein levels in insulin-resistant rats [53]. Moreover, green tea catechins, especially EGCG, could improve insulin resistance by scavenging ROS, which was able to block the transduction of insulin signal and prevent IRS-1 from binding to insulin receptor by decreasing tumor necrosis factor (TNF)- $\alpha$-induced c-jun NH2-terminal kinase (JNK) phosphorylation [48,54]. Furthermore, EGCG played an insulin-like role in down-regulating the gene and protein expression of hepatocyte nuclear factor (HNF4), a key transcription factor controlling gluconeogenesis enzymes, such as phosphoenolpyruvate carboxykinase and glucose-6-phosphatase [55]. Moreover, green tea catechins could promote adipocyte differentiation and increase insulin sensitivity by directly activating peroxisome proliferator-activated receptor $\gamma$ (PPAR $\gamma$ ) [56]. EGCG-enriched green tea extract could also prevent T2DM by stimulating the production of soluble receptors for advanced glycation of end products (sRAGE) through a disintegrin and metallopoteases10 (ADAM10)-induced ectodomain shedding of extracellular RAGE [57].

Black tea regularly had antioxidant and anti-inflammatory effects [58] which could exert effects against T2DM. Black tea, abundant in theaflavins (accounting for $68.4 \%$ tea polyphenols), played a hypoglycemic role by inhibiting the action of ROS, such as singlet oxygen, superoxide, and hydroxyl radicals [20]. Further, black tea could reduce the risk of T2DM by inhibiting obesity through the phosphorylation of key metabolic regulator AMPK and promoting the browning of white adipose tissue [59].

Studies found that white tea had higher levels of tea polyphenols and better antioxidant activity than black tea [60]. White tea could exhibit antidiabetic activity by reducing insulin resistance, 
hyperlipidemia, and oxidative stress [61]. Additionally, white tea lowered blood sugar level by increasing insulin sensitivity and the synthesis of liver glycogen in T2DM rats [62]. Moreover, it was revealed that the combination of white tea and moringa oleifera had a good hypoglycemic effect [63].

It was found that the water extract of pu-erh tea contained less polyphenols but more caffeine, which could improve insulin sensitivity $[5,64]$. An in vitro study found that qingzhuan tea (a type of dark tea) had an inhibitory effect on $\alpha$-glucosidase, which was attributed to EGCG and gallocatechin gallate (GCG) [65]. Pu-erh tea polysaccharides was also reported to regulate postprandial blood sugar by inhibiting $\alpha$-glucosidase but have no effect on $\alpha$-amylase activity, with older pu-erh tea exhibiting a higher inhibitory effect [66]. Moreover, it was found that ripened pu-erh tea had a better effect than raw pu-erh tea on the control of postprandial blood glucose in T2DM mice [67]. Additionally, pu-erh tea polysaccharides promoted adipocyte differentiation and glucose uptake by mimicking the properties of PPAR $\gamma$ and glucose transporter type 4 (GLUT4), ameliorating insulin resistance and lowering blood sugar [68]. Furthermore, Fu brick tea attenuated insulin resistance by down-regulating signal regulatory protein- $\alpha$ (SIRP- $\alpha$ ) expression and activating insulin signaling in a Akt/GLUT4/FoxO1 and the target of rapamycin (mTOR)/S6K1 pathways in the skeletal muscle of male Sprague-Dawley rats [69].

Yellow tea could ameliorate glucose intolerance and insulin resistance without dose dependence [70]. Further, the roasted yellow tea could improve insulin sensitivity and reduce fasting blood sugar due to the strong affinity of GCG to target protein-glycosidase, and the strong inhibition effect of GCG on $\alpha$-glucosidase activity [71].

In general, different types of tea exhibit antidiabetic effects in vitro and in vivo. Tea catechins, theaflavins, polysaccharides, and caffeine should be mainly responsible for the antidiabetic effects of tea. Notably, these bioactive compounds in tea can regulate signal pathways and key molecules involved in the regulation of insulin, blood sugar, and energy metabolism.

\subsection{Diabetic Complications}

\subsubsection{Diabetic Nephropathy}

Diabetic nephropathy is one of the major microvascular complications of diabetes mellitus [72]. Its obvious pathological changes were persistent proteinuria, changes in creatinine clearance, mesangial matrix dilatation, thickening of glomerular basement membrane, and glomerular sclerosis [73]. Numerous studies demonstrated that tea could ameliorate the pathological process of diabetic nephropathy through the antioxidant and anti-inflammatory properties [74,75]. The effects and related molecular mechanisms of tea against diabetic kidney injury are discussed below.

Green tea extract could provide a beneficial effect against long-term diabetic nephropathy via suppressing hyperglycaemia, preventing glycogen accumulation in the proximal tubules, and improving serum and urine parameters (e.g., glucose, glycosylated proteins and creatinine, and blood urea nitrogen) [70]. Green tea could defend renal tubular by reducing the urinary activity of renal tubular epithelial-cell enzymes [76]. Furthermore, green tea catechins could protect kidney function by reducing the permeability of glomerular filtration membrane through inhibiting thrombosis with lowered microsomal phospholipase A2 and regulating arachidonic acid cascade system [42]. An in vivo study also found that green tea could improve glomerular filtration and reduce the rate of creatinine increase and renal hypertrophy [77]. Further, in diabetic spontaneously hypertensive rats (SHRs), green tea prevented podocyte apoptosis and albuminuria by rising $\mathrm{p}$-low-density lipoprotein receptor-related protein 6 (p-LRP6) expression and blocking glycogen synthase kinase 3 interaction with p53 (GSK3-p53) [78]. Another study also found green tea polyphenols could attenuate the urinary protein excretion and characteristic morphological changes of diabetic nephropathy by decreasing blood glucose levels [79]. Additionally, (+)-catechins might ameliorate renal dysfunction in diabetic mice by inhibiting advanced glycation end product (AGE) formation and cutting off inflammatory pathways via trapping metabolite methylglyoxal [80]. Also, green tea catechins could reduce the 
oxidative damage and inflammatory reaction in the kidney by regulating the activity of $5^{\prime}$-lipoxygenase and inhibiting the generation of superoxide radicals, oxidative proteins, lipids, and leukotriene B-4 in the kidneys of diabetic rats [81]. Moreover, green tea flavonoids could reduce ROS via three pathways, including the activation of PPAR $\gamma$ in the eukaryotic elongation factor-2 kinase (EEF2K) pathway by enhancing $5^{\prime} \mathrm{AMPK}$, the induction of nuclear factor-erythrocyte-associated factor 2 (Nrf2), by activating the Kelch-like ECH-associated protein 1-antioxidant-responsive element (Keap1-ARE) signaling, and the regulation of Mn superoxide dismutase production via Forkhead box O3 (FOXO3) -Akt pathway by increasing sirtuin-1 [82]. In addition, green tea catechins, especially EGCG and epicatechin gallate (ECG), could improve the thickening of the basement membrane by relieving the damage of matrix metalloproteinase (MMP), which could degrade extracellular matrix and fibrosis, finally alleviating diabetic nephropathy [83-85].

Besides green tea, other types of tea also show protective effects against diabetic nephropathy. Pu-erh tea could ameliorate diabetic nephropathy by decreasing RAGE expression and glomerular IgG deposit through inhibiting AGE accumulation [73]. Cuiyu tea (a dark tea) polypeptides were reported to stimulate the PKC $\zeta / \mathrm{JNK} /$ nuclear factor- $\mathrm{KB}(\mathrm{NF}-\mathrm{\kappa B}) / \mathrm{THF}-\alpha / \mathrm{iNOS}$, advanced glycation end products (AGEs)/RAGE/TGF-1 pathway, up-regulate the expression of podocin in glomeruli, and decrease the release of proinflammatory cytokines, thereby ameliorating diabetic nephropathy [86]. Further, oolong tea polysaccharides could reduce renal tissue inflammation and improve the glomerular vascular permeability of glutathione peroxidase (GSH-PX) by enhancing the activity of superoxide dismutase and GSH-PX [87]. In general, tea exhibits good effects against diabetic nephropathy in vitro and in vivo.

\subsubsection{Diabetic Cardiovascular Diseases}

Cardiovascular complications, containing cardiomyopathy, atherosclerosis, coronary ischemia, and vascular disease, are associated with the high morbidity and mortality of diabetes mellitus $[77,88]$, among which cardiomyopathy is responsible for $80 \%$ [17]. It was reported that tea could improve cardiovascular complications by decreasing hyperglycemia, adjusting lipid metabolism, activating signaling pathways, down-regulating the inflammatory factors, and so on.

Tea polyphenols could improve myocardial glycolipid energy metabolism and interfere with adiponectin mRNA and protein expression through AMPK activation, which was involved in insulin signaling [89]. Also, tea polyphenols could stimulate the activity of AMPK via the $\mathrm{Ca}^{2+} / \mathrm{Ca}-\mathrm{MKK} /$ AMPK-mediated signaling pathway [90]. Additionally, tea polyphenols could regulate autophagy via mTOR and Akt signaling pathways, which was beneficial for the prevention and treatment of diabetic cardiomyopathy [91-93].

An in vivo study found that green tea could inhibit cardiac dyslipidemia, lipid peroxidation, and protein glycosylation through improving the activities of $\mathrm{Ca}^{2+}$-ATP and $\mathrm{Na}^{+} / \mathrm{K}^{+}$-ATP enzymes to regulate the content of $\mathrm{Ca}^{2+}$ and $\mathrm{Na}^{+}$[94]. Furthermore, EGCG could improve metabolic and cardiovascular pathophysiology by stimulating the production of nitric oxide (NO) from endothelium via phosphatidylinositol 3-hydroxykinase (PI3k)-dependent pathways [95]. Additionally, EGCG could inhibit inflammatory factors such as NF-kB and activator-1, which played an important role in vascular inflammation caused by insulin resistance $[96,97]$. In addition, it was found that green tea extract could reduce the progression of atherosclerosis by reversing endothelial dysfunction [98]. Also, MMP-9 played an important role in atherosclerosis, and green tea catechins could inhibit the mRNA expression and the activity of MMPs $[83,99]$. Further, green tea catechins increased plasma total antioxidant activity and prevented diabetic cardiovascular autonomic dysfunction by blocking changes in arterial pressure variability [77]. Moreover, the green tea extract inhibited the accumulation of aortic collagen, reduced the solubility of collagen, and decreased AGEs and collagen cross-linking, finally preventing diabetic cardiomyopathy in streptozotocin diabetic rats $[98,100]$. It was also reported that green tea flavonoids could alleviate the contraction of aortic strips, and green tea extract could protect against free radical and glucose-mediated protein damage [101]. 
Both black tea theaflavins and green tea catechins significantly attenuated high glucose-induced block of insulin signaling, reduced lipid accumulation, inhibited fatty acid synthesis, and stimulated fatty acid oxidation by activating the LKB1-AMPK pathway [54,102,103]. Furthermore, insulin deficiency and insulin resistance could induce exaggerated vasoconstriction [104], and black tea polyphenols could improve vasoconstriction through PI3K-Akt pathway and endothelial nitric oxide synthase (eNOS) phosphorylation $[105,106]$.

White tea catechins could reduce the absorption of cholesterol in the intestines and increase the excretion of cholesterol and total fat in the feces [107]. Further, white tea could control the Krebs cycle by decreasing pyruvate through regulating lactic acid and the lactate dehydrogenase levels in the heart at the prediabetic state, thereby preventing diabetic cardiovascular disease [108-110]. In addition, white tea could regulate cardiac metabolic disorders by up-regulating the expression of cardiac GLUT1 and GLUT3 mRNA [87]. Quercetin, an important flavonoid found in write tea, could prevent diabetic vascular complications in both insulin deficiency and resistance by inhibiting inflammatory pathways, especially the NF-кB signaling [104].

Yellow tea "Junshan Yinzhen" could improve insulin resistance and the disorders of glucose and lipid metabolism in diabetic rats, which may be related to the high content of polyphenols, polysaccharides, and alkaloids in yellow tea [111]. Besides, yellow tea could control glucose effectively by maintaining normal expression of thioredoxin interacting protein, which played an important role in the synthesis and release of glucose in the liver [112].

Oolong tea contained less catechins than green tea, but more catechins than black tea [113]. Pu-erh tea extract could inhibit inflammation of visceral adipose tissue by down-regulating the inflammatory factors and inducing the expression of G-protein coupled receptor (Gpr120) [114].

Therefore, tea and its bioactive components, can be good protectors for cardiovascular complications of diabetes.

\subsubsection{Diabetic Neuropathy}

Neurodegeneration is characterized by increased free radical production and oxidative stress [115]. It has been proved that tea had neuroprotective effects due to its anti-inflammatory and antioxidant properties [116]. An in vivo study found that green tea could prevent autonomic nervous dysfunction by blocking the change of arterial pressure variability [77]. Furthermore, green tea extract could restore the analgesic effect of morphine on diabetic neuropathic pain by inhibiting the production of NO [117]. Further, EGCG could reduce the formation of neural tube defects in embryo caused by maternal diabetes mellitus in mice through blocking the expression and activity of DNA methyltransferase, and inhibiting DNA hypermethylation, and restoring the expression of neural tube closure essential gene [118]. However, the protective effects of tea other than green tea on diabetic neuropathy have been much less investigated, and it could be interesting to investigate whether other types of tea can be also effective to protect against diabetic neuropathy.

\subsubsection{Diabetic Retinopathy}

Diabetic retinopathy is a common microvascular complication of diabetes mellitus [119]. Hyperglycemia, oxidative stress, and advanced glycation end products are all risk factors of diabetic retinopathy [120]. Tea has shown protective effects on diabetic retinopathy. In diabetic rats, EGCG could protect the retina by decreasing the level of anion and preventing the formation of acellular capillaries and pericyte ghosts [121]. Also, green tea could protect the nerves of diabetic retinas and regulate the subretinal environment by reducing the production of ROS by increasing glutamate transporter expression, reestablishing intercellular connections, and restoring glutamine/glutamate circulation [122]. In addition, green tea at very low dose could improve antioxidant defense, reduce inflammatory markers, and prevent retinal basement membrane thickening [123]. Further, black tea could delay the development of diabetic cataracts by lowering blood sugar, thereby inhibiting pathological biochemical 
indicators [124]. Oolong tea extract could increase plasma retinol levels in diabetic rats [125]. Overall, tea acts as a potent neuroprotector in diabetic retinas.

\subsubsection{Diabetic Hepatopathy}

Diabetic hepatopathy is potentially less common [126] but tends to be more prevalent among children [127]. Several studies suggested that tea and tea polyphenols could play important roles in diabetic liver injury through their antioxidant and anti-inflammatory activities [128,129].

In apparently healthy individuals, green tea extract could reduce oxidative stress and reduce the risk of diabetic liver diseases by lowering the malondialdehyde level and increasing the glutathione level [126]. In addition, green tea could ameliorate liver inflammation and damage caused by diabetes mellitus by lowering angiotensin II receptors [130]. Further, black tea extract protected the liver by increasing cellular antioxidant capacity and reducing membrane lipid peroxidation, inhibiting oxidative stress in diabetic and obese rats caused by alloxan and high cholesterol diets [17]. A dietary supplement of yellow tea and write tea regulated glucose and lipid metabolism by reducing the expression of fatty acid synthase, a membrane surface molecule leading to cell apoptosis, and sterol response element-binding protein $1 \mathrm{in} \mathrm{db} / \mathrm{db}$ mice [15].

Notably, the molecular mechanisms of EGCG on diabetes mellitus and its complications are summarized in Figure 2.

\subsubsection{Other Complications}

Tea is also beneficial for other diabetic complications, such as osteoporosis, periodontal disease, and reproductive dysfunction. For example, green tea could treat periodontal disease by decreasing the expression of pro-inflammatory cytokine TNF- $\alpha$ and the osteoclastogenic mediator receptor activator of the NF-кB ligand (RANKL) and up-regulating the expression of anti-inflammatory cytokine interleukin-10, osteogenesis-related factor runt-related transcription factor 2 (RUNX-2), and anti-osteoclastogenic factor osteoprotegerin (OPG) [131]. Moreover, epigallocatechin (EGC) had a positive effect on bone metabolism by promoting osteoblast activity and inhibiting osteoclast differentiation [132].

\subsection{Adjuvant Therapy}

Currently, acarbose, rosiglitazone, and metformin are the main antidiabetic drugs used in clinics $[66,133]$. Several studies reported that tea had synergistic effects with antidiabetic drugs on diabetes and its complications, making tea a promising adjuvant for diabetes treatment. It was shown that pu-erh tea could enhance the effect of rosiglitazone on antidiabetic nephropathy by preventing the diabetes-induced accumulation of AGEs and re-establishing a normal RAGE level in vivo [69]. Black tea and acarbose also showed a mixed-type effect on the modulation of postprandial hyperglycemia by inhibiting the $\alpha$-glucosidase activity in the small intestine [134]. Low concentrations of green tea polyphenols or EGCG had a synergistic effect with acarbose on $\alpha$-amylase and $\alpha$-glucosidase in vitro [135].

To sum up, a great number of studies indicated that tea and its bioactive components could be used for the prevention and treatment of diabetes mellitus and its complications (Table 2). The main mechanisms of action included protecting pancreatic $\beta$-cells, ameliorating insulin resistance, anti-inflammatory, and antioxidant potentials (Figure 3). Furthermore, tea showed a synergistic effect with certain antidiabetic drugs on diabetes and its complications. 


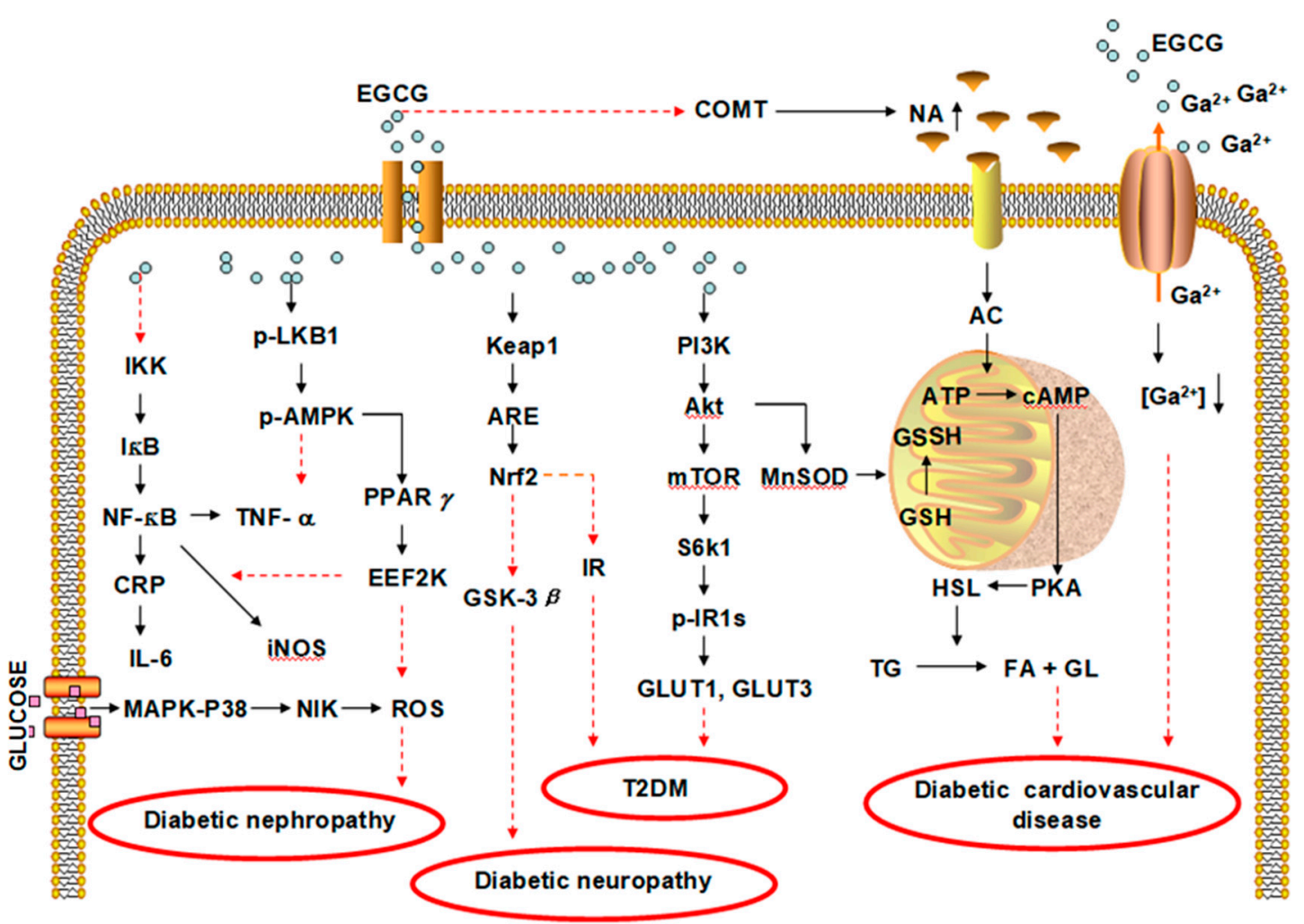

Figure 2. The molecular mechanisms of EGCG against diabetes mellitus and its complications. EGCG has shown effects against T2DM by improving IR, against diabetic cardiovascular disease by decreasing TG and $\left[\mathrm{Ga}^{2+}\right]$, against diabetic nephropathy by decreasing ROS and against diabetic neuropathy by increasing Nrf2. The arrow means the direction of actions, and the black full lines indicate upregulation and red dotted lines refer to downregulation or inhibition. CRP, C-reactive protein; MAPK p38-NIK, NF- $\mathrm{BB}$ inducing kinase; LKB1, kelch-like ECH-associated protein-1; EEF2K, eukaryotic elongation factor-2 kinase; ARE, antioxidant-responsive element; GSK-3 $\beta$, glycogen synthase kinase- $3 \beta$; IR, insulin resistance; MnSOD, Mn superoxide dismutase; NA, noradrenalin; s6k1, ribosomal protein S6 kinase 1; AC, adenylate cyclase; HSL, hormone-sensitive lipase; TG, triglyceride; FA, fatty acid; GL, glycerinum; GSH, glutathione; GSSH, oxidized glutathione; mTOR, the target of rapamycin; EGCG, epigallocatechin gallate; IKK, IкB kinase; NF- $\kappa B$, nuclear factor- $\kappa \mathrm{B}$; iNOS, inducible nitric oxide synthase; TNF- $\alpha$, tumor necrosis factor- $\alpha$; Nrf2, nuclear factor-erythrocyte-associated factor 2; PI3K, phosphatidylinositol 3-hydroxykinase; Akt, protein kinase B; AMPK, adenylic acid-activated protein kinase; T2DM, type 2 diabetes mellitus; GLUT, glucose transporter type; PKA, protein kinase A; ATP, adenosine triphosphate; cAMP, cyclic Adenosine monophosphate; COMT, catechol-O-methyltransferase, an enzyme responsible for the degradation of noradrenalin. 
Table 2. The effects of tea on diabetes mellitus and its complications by in vitro and in vivo studies.

\begin{tabular}{|c|c|c|c|c|c|c|c|c|}
\hline $\begin{array}{c}\text { Tea } \\
\text { Types }\end{array}$ & Constituents & Diseases Types & $\begin{array}{l}\text { Study } \\
\text { Types }\end{array}$ & Models & Dose & Effects & Mechanisms & Ref. \\
\hline \multirow[t]{15}{*}{$\begin{array}{c}\text { Green } \\
\text { tea }\end{array}$} & EGCG & $\begin{array}{l}\text { Diabetic cardiovascular } \\
\text { disease }\end{array}$ & In vivo & $\begin{array}{l}\text { Alloxan-induced diabetic } \\
\text { rabbits }\end{array}$ & $50 \mathrm{mg} / \mathrm{kg} / \mathrm{day}$ & $\begin{array}{l}\text { Improved late endothelial progenitor cells(L-EPCs); } \\
\text { Promoted reendothelialization. }\end{array}$ & Activated Akt/eNOS pathway & [136] \\
\hline & EGCG & Diabetic cardiomyopathy & In vivo & Wistar rats & $50 \mathrm{mg} / \mathrm{kg} / \mathrm{day}$ & $\begin{array}{l}\text { Enhanced cardiac function; } \\
\text { Increased ADSC repair capability; }\end{array}$ & $\begin{array}{l}\uparrow \text { Insulin-like growth factor } 1 \\
\uparrow \mathrm{H} 9 \mathrm{c} 2 \text { cell cycle }\end{array}$ & [137] \\
\hline & EGCG & diabetic neuropathy & In vivo & Male Wistar rats & $0.1 \%(\mathrm{w} / \mathrm{v})$ & Improved cerebral function. & $\begin{array}{l}\downarrow \text { Neuronal degeneration } \\
\downarrow \text { Apoptotic cell death }\end{array}$ & [138] \\
\hline & Polyphenols & Diabetic Retinopathy & In vivo & Wistar-Kyoto rats & $5.7 \mathrm{~g} / \mathrm{kg} / \mathrm{day}$ & Protected the retina against glutamate toxicity. & $\downarrow$ ROS & [122] \\
\hline & Polyphenols & $\begin{array}{l}\text { Diabetic cardiovascular } \\
\text { disease }\end{array}$ & In vivo & Male Wistar rats & $0.8,1.6$, and $3.2 \mathrm{~g} / \mathrm{L}$ & $\begin{array}{l}\text { Reduced fat deposit; } \\
\text { Ameliorated hypoadiponectinemia in HF-fed rats; } \\
\text { Relieved high glucose-induced adiponectin decrease. }\end{array}$ & $\begin{array}{c}\downarrow \text { Extracellular signal regulated } \\
\text { kinase } 1 / 2 \text { phosphorylation } \\
\uparrow \text { PPAR } \gamma \\
\downarrow \text { Adiponectin decrease } \\
\end{array}$ & [139] \\
\hline & Polyphenols & $\begin{array}{l}\text { Diabetic cardiovascular } \\
\text { disease }\end{array}$ & In vitro & Cardiac muscle of rats & $200 \mathrm{mg} / \mathrm{kg}$ & $\begin{array}{l}\text { Ameliorated the effects of high-fructose diet on } \\
\text { insulin signaling, lipid metabolism and inflammation. }\end{array}$ & $\begin{array}{c}\uparrow \text { PI3k, Akt1 } \\
\uparrow \text { Glut1, Glut4, glycogen } \\
\text { synthase } 1 \\
\uparrow \text { Anti-inflammatory protein } \\
\downarrow \text { GSK-3 } 3, \text { TNF, IL-1B and IL-6 } \\
\end{array}$ & [53] \\
\hline & & $\begin{array}{l}\text { Diabetic cardiovascular } \\
\text { disease }\end{array}$ & In vivo & STZ-induced rats & $300 \mathrm{mg} / \mathrm{kg} / \mathrm{day}$ & Protected rat heart. & $\begin{array}{c}\downarrow\left[\mathrm{Ca}^{2+}\right] \text { and }\left[\mathrm{Na}^{+}\right] \\
\uparrow \text { Activities of } \mathrm{Ca}^{2+} \text {-ATPase } \\
\text { and } \mathrm{Na}^{+} / \mathrm{K}^{+} \text {-ATPase }\end{array}$ & [94] \\
\hline & & $\begin{array}{l}\text { Diabetic cardiovascular } \\
\text { disease }\end{array}$ & In vivo & STZ-induced rats & $300 \mathrm{mg} / \mathrm{kg} / \mathrm{day}$ & Reduced the risk of diabetic cardiovascular disease. & $\begin{array}{c}\downarrow \text { Cholesterol, triglyceride } \\
\downarrow \text { Free fatty acid and LDL-C } \\
\uparrow \text { HDL-C }\end{array}$ & [140] \\
\hline & & Diabetic cardiomyopathy & In vivo & Diabetic rats & $300 \mathrm{mg} / \mathrm{kg} /$ day & Treated diabetic cardiomyopathy. & $\begin{array}{c}\downarrow \text { AGEs } \\
\downarrow \text { Ollagen cross-linking } \\
\downarrow\end{array}$ & [100] \\
\hline & & diabetic retinopathy & In vivo & Rats & $200 \mathrm{mg} / \mathrm{kg} /$ day & Prevented and treated diabetic retinopathy. & $\downarrow$ SOD and catalase enzyme & [123] \\
\hline & & Diabetic hepatopathy & In vivo & Male Wistar rats & $1.5 \%(\mathrm{w} / \mathrm{v})$ & Prevented diabetic tissue injury. & $\uparrow$ GSH-Px, SOD, catalase & [126] \\
\hline & & Diabetic hepatopathy & In vivo & Male Wistar rats & $1.5 \%(\mathrm{w} / \mathrm{v})$ & Pretected tissue. & $\begin{array}{c}\uparrow \mathrm{GSH}-\mathrm{Px}, \mathrm{SOD} \text {, catalase } \\
\downarrow \mathrm{MDA} \text {, alkaline phosphatase }\end{array}$ & [141] \\
\hline & & $\begin{array}{l}\text { Diabetic nephropathy } \\
\text { and hepatopathy }\end{array}$ & In vivo & Male Sprague-Dawley rats & $0.1 \%(\mathrm{w} / \mathrm{v})$ & Protected renal and hepatic tissues from injury. & $\begin{array}{c}\uparrow \text { Total antioxidant levels } \\
\downarrow \text { Malonyldialdehyde (MDA) } \\
\downarrow \text { Angiotensin II AT1 receptor }\end{array}$ & [130] \\
\hline & & $\begin{array}{c}\text { Diabetes } \\
\text { mellitus-induced } \\
\text { periodontitis }\end{array}$ & In vivo & STZ-induced rats & N/A & Treated diabetes mellitus-induced periodontitis. & $\begin{array}{c}\downarrow \text { TNF- } \alpha \text { and RANKL } \\
\uparrow \text { RUNX-2, OPG } \\
\uparrow \text { Interleukin-10 (IL-10) }\end{array}$ & [131] \\
\hline & & diabetic spinal cord & In vivo & STZ-induced rats & $\mathrm{N} / \mathrm{A}$ & Improved diabetic spinal cord. & $\uparrow$ GFAP & [142] \\
\hline
\end{tabular}


Table 2. Cont

\begin{tabular}{|c|c|c|c|c|c|c|c|c|}
\hline $\begin{array}{c}\text { Tea } \\
\text { Types }\end{array}$ & Constituents & Diseases Types & $\begin{array}{l}\text { Study } \\
\text { Types }\end{array}$ & Models & Dose & Effects & Mechanisms & Ref. \\
\hline \multirow[t]{6}{*}{ Black tea } & & T1DM & In vivo & Female CD-1 mice & $0.01 \%(w / v)$ & $\begin{array}{l}\text { Promoted insulin secretion and regenerated damaged } \\
\text { pancreas and protected pancreatic } \beta \text { - cells. }\end{array}$ & $\begin{array}{l}\downarrow \text { Nitrosative stressRUNX-2, } \\
\text { OPG } \downarrow \text { ROS }\end{array}$ & [20] \\
\hline & & Diabetes mellitus & In vivo & STZ-induced rats & $0.5 \mathrm{~mL} /$ day & $\begin{array}{l}\text { Regenerated damaged pancreas and protected } \\
\text { pancreatic } \beta \text {-cells. }\end{array}$ & $\downarrow$ Nitrosative stress & [143] \\
\hline & & T2DM & In vivo & STZ-induced rats & $0.01 \mathrm{~mL} / \mathrm{g} / \mathrm{day}$ & $\begin{array}{l}\text { Ameliorated diabetes mellitus associated oxidative } \\
\text { stress. }\end{array}$ & $\uparrow \mathrm{GSH}$ & [144] \\
\hline & & Diabetic complication & In vivo & Diabetic animals & $50 \mathrm{mg} / \mathrm{mL}$ & Attenuated oxidative stress mediated tissue damage. & $\begin{array}{c}\downarrow \text { DNA fragmentation } \\
\downarrow \text { Activation of caspase-3 } \\
\uparrow \text { Oxidative stress related } \\
\text { parameters }\end{array}$ & [108] \\
\hline & & Diabetic tissue injury & In vivo & Adult male Wistar albino rat & $\begin{array}{l}50 \text { and } 100 \\
\mathrm{mg} / \mathrm{kg} / \text { day }\end{array}$ & Protected the liver & $\begin{array}{c}\uparrow \text { Cellular antioxidant capacity } \\
\downarrow \text { Membrane lipid peroxidation } \\
\downarrow \text { Oxidative stress }\end{array}$ & [17] \\
\hline & EGC, GC, GCG & bone metabolism & In vitro & $\begin{array}{l}\text { Cultured rat osteoblast-like } \\
\text { osteosarcoma cell line } \\
\text { UMR-106 }\end{array}$ & N/A & Improved bone metabolism & $\begin{array}{c}\uparrow \text { Osteoblast activity } \\
\downarrow \text { Osteoclast differentiation }\end{array}$ & [132] \\
\hline \multirow[t]{4}{*}{$\begin{array}{l}\text { White } \\
\text { tea }\end{array}$} & & T2DM & In vivo & Male Sprague-Dawley rats & $0.5 \%(w / v)$ & Lowered blood sugar levels. & $\begin{array}{c}\uparrow \text { Insulin sensitivity } \\
\uparrow \text { The synthesis of liver } \\
\text { glycogen }\end{array}$ & [62] \\
\hline & & $\begin{array}{l}\text { Diabetic cardiovascular } \\
\text { diseases }\end{array}$ & In vivo & Male Wistar rats & $0.01 \mathrm{mg} / \mathrm{mL}$ & Prevented cardiovascular diseases. & $\begin{array}{l}\uparrow \text { Insulin sensitivity } \\
\uparrow \text { Cardiac acetate and alanine } \\
\text { contents and protein oxidation }\end{array}$ & [88] \\
\hline & & Diabetes mellitus & In vitro & $\begin{array}{l}\text { human hepatocellular } \\
\text { carcinoma (HepG2) cell }\end{array}$ & $25 \mathrm{mg} / \mathrm{mL}$ & Improved glucose and lipid metabolism. & $\downarrow$ Glucose uptake and transport & {$[145]$} \\
\hline & & $\begin{array}{l}\text { Diabetic reproductive } \\
\text { dysfunction }\end{array}$ & In vivo & $\begin{array}{l}\text { STZ-induced prediabetic rat } \\
\text { model }\end{array}$ & $10 \mathrm{mg} / \mathrm{mL}$ & $\begin{array}{l}\text { Improved epididymal sperm motility and restored } \\
\text { sperm viability. }\end{array}$ & $\begin{array}{l}\downarrow \text { GLUT3 protein } \\
\uparrow \text { Lactate dehydrogenase } \\
\uparrow \text { Lactate content. }\end{array}$ & [146] \\
\hline
\end{tabular}


Table 2. Cont

\begin{tabular}{|c|c|c|c|c|c|c|c|c|}
\hline $\begin{array}{c}\text { Tea } \\
\text { Types }\end{array}$ & Constituents & Diseases Types & $\begin{array}{l}\text { Study } \\
\text { Types }\end{array}$ & Models & Dose & Effects & Mechanisms & Ref. \\
\hline \multirow[t]{7}{*}{ Dark tea } & EGCG, ECG & Diabetes mellitus & In vitro & N/A & $50 \mathrm{mg} / \mathrm{mL}$ & Treated diabetes mellitus. & $\downarrow \alpha$-glucosidase & [65] \\
\hline & TP,TPS & Diabetes mellitus & In vivo & Diabetic rats & $50 \mathrm{mg} / \mathrm{kg}$ & Reduced postprandial blood sugar. & $\downarrow \alpha$-glucosidase & [147] \\
\hline & Polysaccharides & T2DM & In vivo & Male ICR mice & $40 \mathrm{mg} / \mathrm{kg}$ & $\begin{array}{l}\text { Lowered the blood glucose levels and reversed } \\
\text { oxidative stress. }\end{array}$ & $\begin{array}{c}\uparrow \text { SOD activity } \\
\uparrow \text { Malondialdehyde contents } \\
\uparrow \text { GSH-Px }\end{array}$ & [148] \\
\hline & & T2DM & In vivo & Male ICR mice & 1 and $5 \mathrm{mg} / \mathrm{kg}$ & Improved insulin resistance. & $\begin{array}{c}\downarrow \alpha \text {-glucosidase } \\
\text { Maintain } \alpha \text {-amylase }\end{array}$ & [66] \\
\hline & & T2DM & $\begin{array}{l}\text { In vitro } \\
\text { In vivo }\end{array}$ & $\begin{array}{l}\text { HepG2 cells } \\
\mathrm{db} / \mathrm{db} \text { mice }\end{array}$ & $\begin{array}{l}100,200, \text { and } 400 \\
\mathrm{mg} / \mathrm{kg} / \mathrm{day}\end{array}$ & $\begin{array}{l}\text { Improved insulin resistance and maintained glucose } \\
\text { homeostasis. }\end{array}$ & $\begin{array}{c}\uparrow \text { Glucose uptake } \\
\downarrow \text { Intestinal sucrase, maltase, } \\
\text { and porcine pancreatic amylase } \\
\text { activity }\end{array}$ & [5] \\
\hline & & T2DM & In vivo & Male Sprague-Dawley rats & 400 mg/kg/day & $\begin{array}{l}\text { Alleviated insulin resistance and chronic kidney } \\
\text { disease. }\end{array}$ & $\begin{array}{c}\downarrow \text { SIRP- } \alpha \\
\uparrow \text { PI3K/Akt } \\
\uparrow \text { Nrf2 expression in kidney } \\
\downarrow \text { GSK-3 } 3 \text { phosphorylation } \\
\text { Activated Akt/GLUT4, FoxO1 } \\
\text { and mTOR/S6k1 pathways }\end{array}$ & [69] \\
\hline & & diabetic nephropathy & In vivo & $\mathrm{db} / \mathrm{db}$ mice and $\mathrm{db} / \mathrm{m}$ mice & $1 \mathrm{~g} / \mathrm{kg} / \mathrm{day}$ & $\begin{array}{l}\text { Attenuated the increases in urinary albumin, serum } \\
\text { creatinine, and mesangial matrix. }\end{array}$ & $\begin{array}{c}\downarrow \text { AGEs } \\
\downarrow \text { Receptor for AGE expression } \\
\quad \text { in glomeruli } \\
\downarrow \text { Carbonyl compounds }\end{array}$ & [73] \\
\hline \multirow[t]{2}{*}{$\begin{array}{c}\text { Onloog } \\
\text { tea }\end{array}$} & Polysaccharide & $\begin{array}{l}\text { diabetic tissue and } \\
\text { kidney }\end{array}$ & In vivo & $\begin{array}{l}\text { STZ-induced diabetic } \\
\text { diabetic mice }\end{array}$ & $\begin{array}{l}50,100, \text { and } 200 \\
\mathrm{mg} / \mathrm{kg}\end{array}$ & Prevented diabetic tissue and kidney diseases. & $\begin{array}{c}\uparrow \text { SOD and GSH-PX activity } \\
\downarrow \text { MDA }\end{array}$ & {$[87]$} \\
\hline & Polysaccharide & Diabetic immune disease & In vivo & STZ-induced diabetic mice & $\begin{array}{l}100,300, \text { and } 600 \\
\mathrm{mg} / \mathrm{kg} \text { in mice } \\
50,100, \text { and } 200 \\
\mathrm{mg} / \mathrm{kg} \text { in rats }\end{array}$ & Improved immunomodulatory function. & $\begin{array}{l}\uparrow \text { The activity of NK } \\
\text { cellsIntensify DTH } \\
\uparrow \text { Phagocytotic function of } \\
\text { peritoneal macrophage }\end{array}$ & [149] \\
\hline \multirow[t]{2}{*}{$\begin{array}{c}\text { Yellow } \\
\text { tea }\end{array}$} & EGCGGCG & Diabetes mellitus & In vitro & N/A & $1 \%(\mathrm{w} / \mathrm{v})$ & $\begin{array}{l}\text { CGC reduced postprandial blood sugar more } \\
\text { effectively. }\end{array}$ & $\downarrow \alpha$-glucosidase & [71] \\
\hline & & Diabetic complications & In vivo & $\mathrm{db} / \mathrm{db}$ mice & N/A & $\begin{array}{l}\text { Lowered the serum total and low-density lipoprotein } \\
\text { cholesterol and triglyceride levels. } \\
\text { Increased glucose tolerance. }\end{array}$ & $\begin{array}{c}\downarrow \text { The lipid synthesis } \\
\downarrow \text { SRET fator1, SREP } 1 \\
\downarrow \text { Acetyl-CoA carboxylase } \alpha, \\
\downarrow \text { Fatty acid synthase }\end{array}$ & [15] \\
\hline
\end{tabular}


Table 2. Cont.

\begin{tabular}{|c|c|c|c|c|c|c|c|c|}
\hline $\begin{array}{c}\text { Tea } \\
\text { Types }\end{array}$ & Constituents & Diseases Types & $\begin{array}{l}\text { Study } \\
\text { Types }\end{array}$ & Models & Dose & Effects & Mechanisms & Ref. \\
\hline \multirow[t]{10}{*}{ Tea } & EGCG & T1DM & In vitro & RINm5F cells & $20-40 u \mathrm{M}$ & $\begin{array}{l}\text { Protected pro-inflammatory cytokine and induced } \\
\text { injuries in insulin-producing cells. }\end{array}$ & $\downarrow$ iNOS and NO & [47] \\
\hline & & T1DM & in vivo & C57BL/KsJ mice & $100 \mathrm{mg} / \mathrm{kg} /$ day & Protected pancreatic islets. & $\downarrow$ iNOS & [150] \\
\hline & EGCG & T2DM & In vivo & Diabetic patients & $\begin{array}{l}\text { 300, 600, and } 900 \\
\mathrm{mg} / \text { day }\end{array}$ & $\begin{array}{l}\text { Decreased pathogenesis of proinflammation and } \\
\text { improved diabetes mellitus. }\end{array}$ & $\begin{array}{c}\downarrow \text { Free radicals } \\
\downarrow \text { S100A12-RAGE axis by } \\
\text { stimulating SRAGE }\end{array}$ & [57] \\
\hline & Catechins & T2DM & $\begin{array}{l}\text { In vivo } \\
\text { In vitro }\end{array}$ & $\begin{array}{l}\text { Male obese KK-ay and } \\
\text { C57BL/6J mice; } \\
\text { 3T3-L1 adipocytes }\end{array}$ & $20 \mathrm{mg} / \mathrm{kg} /$ day & $\begin{array}{l}\text { Decreased glucose levels and increased glucose } \\
\text { tolerance in animals. }\end{array}$ & 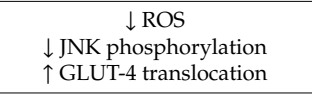 & [48] \\
\hline & EGCG & T2DM & In vitro & Human HepG2 cells & N/A & Attenuated insulin signaling blockade. & $\begin{array}{l}\downarrow \text { Phosphorylation of IRS- } 1 \\
\uparrow 5^{\prime} \text { AMPK }\end{array}$ & [52] \\
\hline & EGCG & T2DM & In vivo & Sprague-Dawley rats & $1-100 u \mathrm{M}$ & $\begin{array}{l}\text { Improved endothelial dysfunction and insulin } \\
\text { resistance and protected against myocardial } I / R \\
\text { injury. }\end{array}$ & $\begin{array}{l}\uparrow \text { NO via PI3k pathway } \\
\uparrow \text { Plasma adiponectin }\end{array}$ & [95] \\
\hline & & diabetic nephropathy & In vivo & Diabetic SHR rats & $5.7 \mathrm{~g} / \mathrm{kg} /$ day & $\begin{array}{l}\text { Reduced podocyte apoptosis, foot process effacement } \\
\text { and albuminuria. }\end{array}$ & $\begin{array}{l}\downarrow \text { GSK3-p53 } \\
\uparrow \text { LRP6 }\end{array}$ & [78] \\
\hline & & diabetic nephropathy & In vivo & STZ-induced diabetic rats & $5 \%(w / v)$ & Improved diabetic nephropathy. & $\begin{array}{l}\downarrow \text { MMP-9, TIMP-1 } \\
\uparrow \text { MMP-2, } \text {,TIMP-2 }\end{array}$ & [83] \\
\hline & & diabetic nephropathy & In vivo & Male Sprague-Dawley rats & $\begin{array}{l}0.25 \% \text { and } 0.5 \% \\
(w / w)\end{array}$ & $\begin{array}{l}\text { Reduced renal oxidative damage and inflammatory } \\
\text { reactions. }\end{array}$ & $\begin{array}{c}\uparrow \text { Activity of 5'-lipoxygenase } \\
\downarrow \text { Ieukotriene B-4 }\end{array}$ & [81] \\
\hline & Catechins & diabetic nephropathy & In vivo & Sprague-Dawley rats & $\begin{array}{c}0.25 \% \text { and } 0.5 \% \\
(\mathrm{w} / \mathrm{w})\end{array}$ & Improved kidney function. & $\begin{array}{c}\downarrow \text { Thromboxane A(2) synthesis } \\
\quad \uparrow \text { Prostacyclin synthesis } \\
\end{array}$ & {$[151,152]$} \\
\hline
\end{tabular}

Abbreviations: iNOS, inducible nitric oxide synthase; RANKL, receptor activator of nuclear factor kappa-B ligand; OPG, osteoprotegerin; RUNX-2, runt-related transcription factor 2; GFAP, glial fibriliary acidic protein; SRET, sterol regulatory element-binding transcription factor 1; SREP, synthase and sterol response element-binding protein; TIMP, tissue inhibitor of metalloproteinases; STZ, streptozotocin; SHR, spontaneous hypertension rat, ICR, Institute of Cancer Research; Akt, protein kinase B; eNOS, endothelial nitric oxide synthase; PPAR $\gamma$, peroxisome proliferator-activated receptor $\gamma$; PI3K, phosphatidylinositol 3-hydroxykinase; GLUT, glucose transporter type; GSK-3 $\beta$, glycogen synthase kinase-3 $\beta$; TNF, tumor necrosis factor; AGEs, advanced glycation end products; SOD, superoxide dismutase; GSH-Px, glutathione peroxidase; SIRP, signal regulatory protein; Nrf2, nuclear factor-erythrocyte-associated factor 2; mTOR, the target of rapamycin; S6k1, ribosomal protein S6 kinase 1; JNK, jun NH2-terminal kinase; w/v, weight/volume; w/w, weight/weight. 
Protect pancreatic $\beta$-cell

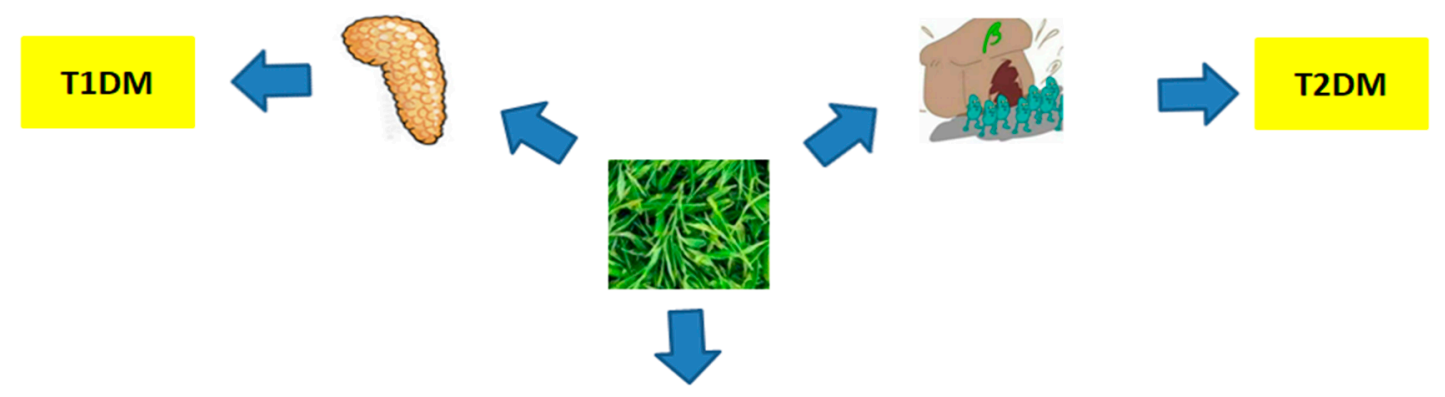

Anti-inflammatory and antioxidant properties

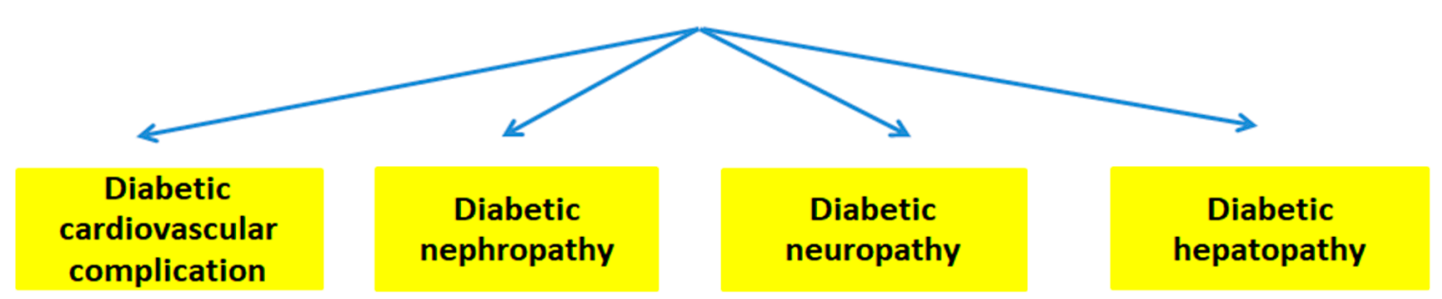

Figure 3. The association between tea and diabetes and its complications. Tea has effects on type 1 diabetes mellitus (T1DM) and type 2 diabetes mellitus (T2DM) by protecting pancreatic $\beta$-cells and ameliorating insulin resistance. Besides, due to the anti-inflammatory and antioxidant properties of tea, diabetic complications, including diabetic cardiovascular complication, diabetic nephropathy, diabetic neuropathy, and diabetic hepatic tissue injury, could be prevented and treated by tea and its bioactive components.

\section{Clinical Trials}

Several clinical trials have assessed the role of tea in treating diabetes mellitus and diabetic complications.

A double-blind, randomized, controlled clinical trial (RCT) found that green tea could improve bone mineral levels in patients from Brazil with diabetes mellitus [153]. Another RCT observed that green tea extract significantly reduced bone resorption markers and altered bone conversion in T2DM patients [154]. Furthermore, a phase I clinical trial involving 63 patients with T2DM found that drinking 4 cups of green tea per day for two months significantly reduced body weight and systolic blood pressure [155]. Another RCT conducted in Taiwan observed that green tea extract significantly improved insulin resistance and increased glucagon-like peptide 1 [156]. It was proven that green tea could reduce risk factors of diabetes mellitus such as average arterial pressure, waist-to-hip ratio, and glutamic-pyruvic transaminase, but had little effect on fasting blood sugar and hemoglobin A1c (HbA1c), which may be related to the short time span of the study, for subjects in Mauritius [21]. Another RCT conducted in British showed that green tea extract could reduce proteinuria in diabetic patients [41]. Further, it was reported that postprandial blood sugar could be decreased in people drinking black tea [39]. A clinical trial conducted in Kuwait also revealed that drinking black tea for one year could significantly reduce $\mathrm{HbA} 1 \mathrm{c}$ level and pro-inflammatory $\mathrm{CD}^{+} \mathrm{CD}^{+} \mathrm{IL}^{-17^{+}}$cells, and eliminate serum total cholesterol, thereby preventing diabetes mellitus and its complications [22]. Moreover, another trial demonstrated that black tea could protect against diabetes mellitus and diabetic cardiovascular disease through its anti-inflammatory and antioxidant properties [58]. Oolong tea was proven to be an effective adjunctive oral hypoglycemic substance for T2DM in a clinical trial in diabetic patients from Taiwan taking normal hypoglycemic drugs [157].

In brief, clinical trials involving different countries and different people showed that tea could prevent and manage diabetes mellitus and its complications, mainly by improving insulin resistance and decreasing postprandial blood sugar (Table 3). 
Table 3. The effects of tea on diabetes mellitus and its complications based on clinical trials.

\begin{tabular}{|c|c|c|c|c|c|c|}
\hline Tea Types & Diseases Types & Study Types & Participants & Dose and Duration & Results & Ref. \\
\hline Green tea & Diabetes mellitus & RCT & $\begin{array}{l}\text { Patients with T2DM } \\
\qquad(\mathrm{N}=63)\end{array}$ & $0,2,4$ cups per day & $\begin{array}{l}\downarrow \text { Body weight, body mass } \\
\text { index, waist circumference } \\
\text { and systolic blood pressure. }\end{array}$ & [155] \\
\hline Green tea & $\begin{array}{c}\text { Diabetic } \\
\text { osteoporosis }\end{array}$ & RCT & $\begin{array}{l}\text { Patients with diabetes } \\
\text { mellitus }(\mathrm{N}=35)\end{array}$ & $\begin{array}{l}1120 \text { mg polyphenols } \\
\text { per day }\end{array}$ & $\begin{array}{c}\uparrow \text { Bone mineral content } \\
\downarrow \text { PTH }\end{array}$ & [153] \\
\hline Green tea & $\begin{array}{c}\text { Bone turnover } \\
\text { induced by diabetes } \\
\text { mellitus }\end{array}$ & RCT & $\begin{array}{l}\text { Patients with T2DM } \\
\qquad(\mathrm{N}=72)\end{array}$ & $500 \mathrm{mg}$ per day & 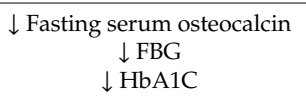 & [154] \\
\hline Oolong tea & T2DM & N/A & Patients with T2DM & $1500 \mathrm{~mL}$ per day & $\begin{array}{l}\downarrow \text { Concentrations of plasma } \\
\text { glucose and fructosamine }\end{array}$ & [73] \\
\hline $\begin{array}{l}\text { Green and } \\
\text { black tea }\end{array}$ & T2DM & RCT & $\begin{array}{l}\text { White persons } \\
\qquad(\mathrm{N}=49)\end{array}$ & $\begin{array}{l}0,375, \text { or } 750 \text { mg per } \\
\text { day for } 3 \text { months }\end{array}$ & $\begin{array}{c}\text { No significant effect on } \\
\text { T2DM. }\end{array}$ & [159] \\
\hline
\end{tabular}

N/A, not available; RCT, randomized, controlled clinical trial; FBG, Fasting blood glucose; T2DM, type 2 diabetes mellitus; PTH, parathyroid hormone; HbA1C, hemoglobin A1c.

\section{Conclusions}

Diabetes mellitus and its complications have become an important public health problem. Epidemiological studies found that drinking tea could reduce the risk of diabetes mellitus and diabetic complications, and among these studies, green tea, black tea, and oolong tea were in the majority, while epidemiological studies on white tea, dark tea, and yellow tea were less common. In addition, experimental studies have shown that tea could protect against diabetes mellitus and diabetic complications by improving insulin resistance, activating the insulin signaling pathway, playing an insulin-like role, improving oxidative stress, and alleviating inflammatory response. Further, tea has synergistic effects with certain antidiabetic drugs. Moreover, clinical trials have shown that tea played a positive role in the prevention and treatment of diabetes mellitus and its complications. Additionally, different types of tea have different main bioactive ingredients, which may be applicable to different diabetic complications. Therefore, tea could be used as a beverage, or be developed into functional foods or nutraceuticals, for the prevention and management of diabetes mellitus and its complications, such as diabetic nephropathy, diabetic cardiovascular disease, and diabetic retinopathy. In the future, more bioactive components in tea for the prevention and management of diabetes mellitus and its complications should be separated and identified, especially for the dark tea. The molecular mechanisms of tea and its bioactive components should be further studied. In addition, because of the differences of doses and effects of tea between experimental and clinical studies, it is still difficult to conclude whether the effective doses from animal studies might have beneficial effects on human. Therefore, more clinical trials should be carried out to verify the protective effects of tea on diabetes mellitus and its complications. In addition, special attention should be paid to the safety of tea and tea products.

Author Contributions: Conceptualization, J.-M.M., R.-Y.G. and H.-B.L.; writing-original draft preparation, J.-M.M., S.-Y.C. and X.-Y.X.; writing-review and editing, X.-L.W., Y.-F.W., S.-X.C., P.-Z.Z., R.-Y.G., and H.-B.L.; supervision, R.-Y.G. and H.-B.L.; funding acquisition, R.-Y.G. and H.-B.L.

Funding: This study was supported by the National Key R\&D Program of China (No. 2018YFC1604400), Shanghai Basic and Key Program (No. 18JC1410800), the Agri-X Interdisciplinary Fund of Shanghai Jiao Tong University (No. Agri-X2017004), and the Key Project of Guangdong Provincial Science and Technology Program (No. 2014B020205002). 
Conflicts of Interest: The authors declare no conflict of interest.

\section{References}

1. Assoc, A.D. Diagnosis and classification of diabetes mellitus. Diabetes Care 2014, 37, S81-S90.

2. Whiting, D.R.; Guariguata, L.; Weil, C.; Shaw, J. IDF diabetes atlas: Global estimates of the prevalence of diabetes for 2011 and 2030. Diabetes Res. Clin. Pract. 2011, 94, 311-321. [CrossRef] [PubMed]

3. Shaw, J.E.; Sicree, R.A.; Zimmet, P.Z. Global estimates of the prevalence of diabetes for 2010 and 2030. Diabetes Res. Clin. Pract. 2010, 87, 4-14. [CrossRef] [PubMed]

4. Guariguata, L.; Whiting, D.R.; Hambleton, I.; Beagley, J.; Linnenkamp, U.; Shaw, J.E. Global estimates of diabetes prevalence for 2013 and projections for 2035. Diabetes Res. Clin. Pract. 2014, 103, 137-149. [CrossRef] [PubMed]

5. Du, W.H.; Peng, S.M.; Liu, Z.H.; Shi, L.; Tan, L.F.; Zou, X.Q. Hypoglycemic effect of the water extract of Pu-erh tea. J. Agric. Food Chem. 2012, 60, 10126-10132. [CrossRef]

6. Li, Y.; Wang, C.; Huai, Q.; Guo, F.; Liu, L.; Feng, R.; Sun, C. Effects of tea or tea extract on metabolic profiles in patients with type 2 diabetes mellitus: A meta-analysis of ten randomized controlled trials. Diabetes Res. Clin. Pract. 2016, 32, 2-10. [CrossRef] [PubMed]

7. Gan, R.Y.; Li, H.B.; Sui, Z.Q.; Corke, H. Absorption, metabolism, anti-cancer effect and molecular targets of epigallocatechin gallate (EGCG): An updated review. Crit. Rev. Food Sci. Nutr. 2018, 58, 924-941. [CrossRef]

8. Li, F.; Li, S.; Li, H.-B.; Deng, G.-F.; Ling, W.-H.; Xu, X.-R. Antiproliferative activities of tea and herbal infusions. Food Funct. 2013, 4, 530-538. [CrossRef]

9. Li, S.; Gan, L.-Q.; Li, S.-K.; Zheng, J.-C.; Xu, D.-P.; Li, H.-B. Effects of herbal infusions, tea and carbonated beverages on alcohol dehydrogenase and aldehyde dehydrogenase activity. Food Funct. 2014, 5, 42-49. [CrossRef]

10. Li, Y.; Li, S.; Lin, S.-J.; Zhang, J.-J.; Zhao, C.-N.; Li, H.-B. Microwave-assisted extraction of natural antioxidants from the exotic gordonia axillaris fruit: Optimization and identification of phenolic compounds. Molecules 2017, 22, 1481. [CrossRef]

11. Meng, X.; Li, S.; Li, Y.; Gan, R.Y.; Li, H.B. Gut microbiota's relationship with liver disease and role in hepatoprotection by dietary natural products and probiotics. Nutrients 2018, 10, 1457. [CrossRef] [PubMed]

12. Meng, X.; Li, Y.; Li, S.; Gan, R.-Y.; Li, H.-B. Natural products for prevention and treatment of chemical-induced liver injuries. Compr. Rev. Food. Sci. Food Saf. 2018, 17, 472-495. [CrossRef]

13. Tao, J.; Li, S.; Gan, R.-Y.; Zhao, C.-N.; Meng, X.; Li, H.-B. Targeting gut microbiota with dietary components on cancer: Effects and potential mechanisms of action. Crit. Rev. Food Sci. Nutr. 2019, 1-13. [CrossRef] [PubMed]

14. Xu, X.-Y.; Zhao, C.-N.; Cao, S.-Y.; Tang, G.-Y.; Gan, R.-Y.; Li, H.-B. Effects and mechanisms of tea for the prevention and management of cancers: An updated review. Crit. Rev. Food Sci. Nutr. 2019, 1-13. [CrossRef] [PubMed]

15. Teng, Y.; Li, D.X.; Guruvaiah, P.; Xu, N.; Xie, Z.W. Dietary supplement of large yellow tea ameliorates metabolic syndrome and attenuates hepatic steatosis in $\mathrm{db} / \mathrm{db}$ Mice. Nutrients 2018, 10, 75. [CrossRef] [PubMed]

16. Ning, J.M.; Li, D.X.; Luo, X.J.; Ding, D.; Song, Y.S.; Zhang, Z.Z.; Wan, X.C. Stepwise identification of six tea (camellia sinensis (L.)) categories based on catechins, caffeine, and theanine contents combined with fisher discriminant analysis. Food Anal. Meth. 2016, 9, 3242-3250. [CrossRef]

17. Ramadan, G.; El-Beih, N.M.; El-Ghffar, E.A.A. Modulatory effects of black v. green tea aqueous extract on hyperglycaemia, hyperlipidaemia and liver dysfunction in diabetic and obese rat models. Br. J. Nutr. 2009, 102, 1611-1619. [CrossRef]

18. Jing, Y.L.; Han, G.J.; Hu, Y.; Bi, Y.; Li, L.R.; Zhu, D.L. Tea consumption and risk of type 2 diabetes: A meta-analysis of cohort studies. J. Gen. Intern. Med. 2009, 24, 557-562. [CrossRef]

19. Boggs, D.A.; Rosenberg, L.; Ruiz-Narvaez, E.A.; Palmer, J.R. Coffee, tea, and alcohol intake in relation to risk of type 2 diabetes in African American women. Am. J. Clin. Nutr. 2010, 92, 960-966. [CrossRef]

20. Tang, W.P.; Li, S.M.; Liu, Y.; Huang, M.T.; Ho, C.T. Anti-diabetic activity of chemically profiled green tea and black tea extracts in a type 2 diabetes mice model via different mechanisms. J. Funct. Foods 2013, 5, 1784-1793. [CrossRef] 
21. Toolsee, N.A.; Aruoma, O.I.; Gunness, T.K.; Kowlessur, S.; Dambala, V.; Murad, F.; Googoolye, K.; Daus, D.; Indelicato, J.; Rondeau, P.; et al. Effectiveness of green tea in a randomized human cohort: Relevance to diabetes and its complications. BioMed Res. Int. 2013, 2013, 412379. [CrossRef] [PubMed]

22. Mahmoud, F.; Haines, D.; Al-Ozairi, E.; Dashti, A. Effect of black tea consumption on intracellular cytokines, regulatory T cells and metabolic biomarkers in type 2 diabetes patients. Phytother. Res. 2016, 30, 454-462. [CrossRef] [PubMed]

23. Hinkle, S.N.; Laughon, S.K.; Catov, J.M.; Olsen, J.; Bech, B.H. First trimester coffee and tea intake and risk of gestational diabetes mellitus: A study within a national birth cohort. BJOG Int. J. Obstet. Gynaecol. 2015, 122, 420-428. [CrossRef] [PubMed]

24. Greenberg, J.A.; Axen, K.V.; Schnoll, R.; Boozer, C.N. Coffee, tea and diabetes: The role of weight loss and caffeine. Int. J. Obes. 2005, 29, 1121-1129. [CrossRef] [PubMed]

25. Hamer, M.; Witte, D.R.; Mosdol, A.; Marmot, M.G.; Brunner, E.J. Prospective study of coffee and tea consumption in relation to risk of type 2 diabetes mellitus among men and women: The whitehall II study. Br. J. Nutr. 2008, 100, 1046-1053. [CrossRef] [PubMed]

26. Hirata, A.; Ohnaka, K.; Tashiro, N.; Wang, Z.; Kohno, M.; Kiyohara, C.; Kono, S.; Takayanagi, R. Effect modification of green tea on the association between rice intake and the risk of diabetes mellitus: A prospective study in Japanese men and women. Asia Pac. J. Clin. Nutr. 2017, 26, 545-555. [PubMed]

27. Odegaard, A.O.; Pereira, M.A.; Koh, W.P.; Arakawa, K.; Lee, H.P.; Yu, M.C. Coffee, tea, and incident type 2 diabetes: The Singapore chinese health study. Am. J. Clin. Nutr. 2008, 88, 979-985. [CrossRef]

28. Iso, H.; Date, C.; Wakai, K.; Fukui, M.; Tamakoshi, A.; Grp, J.S. The relationship between green tea and total caffeine intake and risk for self-reported type 2 diabetes among Japanese adults. Ann. Intern. Med. 2006, 144, 554-562. [CrossRef]

29. Nguyen, C.T.; Lee, A.H.; Pham, N.M.; Do, V.V.; Ngu, N.D.; Tran, B.Q.; Binns, C. Habitual tea drinking associated with a lower risk of type 2 diabetes in Vietnamese adults. Asia Pac. J. Clin. Nutr. 2018, 27, 701-706.

30. Ma, Q.H.; Chen, D.D.; Sun, H.P.; Yan, N.; Xu, Y.; Pan, C.W. Regular Chinese green tea consumption is protective for diabetic retinopathy: A clinic-based case-control study. J. Diabetes Res. 2015, 2015, 231570. [CrossRef]

31. Yi, D.Q.; Tan, X.R.; Zhao, Z.G.; Cai, Y.M.; Li, Y.M.; Lin, X.Y.; Lu, S.L.; Chen, Y.S.; Zhang, Q.Y. Reduced risk of dyslipidaemia with oolong tea consumption: A population-based study in southern China. Br. J. Nutr. 2014, 111, 1421-1429. [CrossRef] [PubMed]

32. Panagiotakos, D.B.; Lionis, C.; Zeimbekis, A.; Gelastopoulou, K.; Papairakleous, N.; Das, U.N.; Polychronopoulos, E. Long-term tea intake is associated with reduced prevalence of (type 2) diabetes mellitus among elderly people from mediterranean islands: MEDIS epidemiological study. Yonsei Med. J. 2009, 50, 31-38. [CrossRef] [PubMed]

33. Huxley, R.; Lee, C.M.Y.; Barzi, F.; Timmermeister, L.; Czernichow, S.; Perkovic, V.; Grobbee, D.E.; Batty, D.; Woodward, M. Coffee, Decaffeinated coffee, and tea consumption in relation to incident type 2 diabetes mellitus: A systematic review with meta-analysis. Arch. Intern. Med. 2009, 169, 2053-2063. [CrossRef] [PubMed]

34. Yang, W.S.; Wang, W.Y.; Fan, W.Y.; Deng, Q.; Wang, X. Tea consumption and risk of type 2 diabetes: A dose-response meta-analysis of cohort studies. Br. J. Nutr. 2014, 111, 1329-1339. [CrossRef] [PubMed]

35. Yang, J.; Mao, Q.X.; Xu, H.X.; Ma, X.; Zeng, C.Y. Tea consumption and risk of type 2 diabetes mellitus: A systematic review and meta-analysis update. BMJ Open 2014, 4, e005632. [CrossRef] [PubMed]

36. Hayashino, Y.; Fukuhara, S.; Okamura, T.; Tanaka, T.; Ueshima, H.; Grp, H.-O.R. High oolong tea consumption predicts future risk of diabetes among Japanese male workers: A prospective cohort study. Diabetic Med. 2011, 28, 805-810. [CrossRef] [PubMed]

37. Wang, X.; Tian, J.; Jiang, J.; Li, L.; Ying, X.; Tian, H.; Nie, M. Effects of green tea or green tea extract on insulin sensitivity and glycaemic control in populations at risk of type 2 diabetes mellitus: A systematic review and meta-analysis of randomised controlled trials. J. Hum. Nutr. Diet. 2014, 27, 501-512. [CrossRef] [PubMed]

38. Yu, J.Y.; Song, P.G.; Perry, R.; Penfold, C.; Cooper, A.R. The effectiveness of green tea or green tea extract on insulin resistance and glycemic control in type 2 diabetes mellitus: A meta-analysis. Diabetes Metab. J. 2017, 41, 251-262. [CrossRef] [PubMed] 
39. Butacnum, A.; Chongsuwat, R.; Bumrungpert, A. Black tea consumption improves postprandial glycemic control in normal and pre-diabetic subjects: A randomized, double-blind, placebo-controlled crossover study. Asia Pac. J. Clin. Nutr. 2017, 26, 59-64.

40. Van Woudenbergh, G.J.; Kuijsten, A.; Drogan, D.; Van Der, A.D.L.; Romaguera, D.; Ardanaz, E.; Amiano, P.; Barricarte, A.; Beulens, J.W.J.; Boeing, H.; et al. Tea consumption and incidence of type 2 diabetes in europe: The EPIC-interact case-cohort study. PLoS ONE 2012, 7, e36910.

41. Borges, C.M.; Papadimitriou, A.; Duarte, D.A.; Lopes de Faria, J.M.; Lopes de Faria, J.B. The use of green tea polyphenols for treating residual albuminuria in diabetic nephropathy: A double-blind randomised clinical trial. Sci. Rep. 2016, 6, 28282. [CrossRef] [PubMed]

42. Nunes, A.R.; Alves, M.G.; Moreira, P.I.; Oliveira, P.F.; Silva, B.M. Can tea consumption be a safe and effective therapy against diabetes mellitus-induced neurodegeneration? Curr. Neuropharmacol. 2014, 12, 475-489. [CrossRef] [PubMed]

43. Islam, M.S.; Choi, H. Green tea, anti-diabetic or diabetogenic: A dose response study. Biofactors 2007, 29, 45-53. [CrossRef] [PubMed]

44. Wang, H.J.; Shi, S.S.; Bao, B.; Li, X.J.; Wang, S.C. Structure characterization of an arabinogalactan from green tea and its anti-diabetic effect. Carbohydr. Polym. 2015, 124, 98-108. [CrossRef] [PubMed]

45. Chemler, J.A.; Lock, L.T.; Koffas, M.A.; Tzanakakis, E.S. Standardized biosynthesis of flavan-3-ols with effects on pancreatic $\beta$-cell insulin secretion. Appl. Microbiol. Biotechnol. 2007, 77, 797-807. [CrossRef] [PubMed]

46. Pastoriza, S.; Mesias, M.; Cabrera, C.; Rufian-Henares, J.A. Healthy properties of green and white teas: An update. Food Funct. 2017, 8, 2650-2662. [CrossRef] [PubMed]

47. Zhang, Z.; Ding, Y.; Dai, X.; Wang, J.; Li, Y. Epigallocatechin-3-gallate protects pro-inflammatory cytokine induced injuries in insulin-producing cells through the mitochondrial pathway. Eur. J. Pharmacol. 2011, 670, 311-316. [CrossRef]

48. Yan, J.Q.; Zhao, Y.; Suo, S.; Liu, Y.; Zhao, B.L. Green tea catechins ameliorate adipose insulin resistance by improving oxidative stress. Free Radic. Biol. Med. 2012, 52, 1648-1657. [CrossRef]

49. Ortsater, H.; Grankvist, N.; Wolfram, S.; Kuehn, N.; Sjoholm, A. Diet supplementation with green tea extract epigallocatechin gallate prevents progression to glucose intolerance in $\mathrm{db} / \mathrm{db}$ mice. Nutr. Metab. 2012, 9, 11. [CrossRef]

50. Ma, X.; Tsuda, S.; Yang, X.; Gu, N.; Tanabe, H.; Oshima, R.; Matsushita, T.; Egawa, T.; Dong, A.J.; Zhu, B.W.; et al. Pu-erh tea hot-water extract activates Akt and induces insulin-independent glucose transport in rat skeletal muscle. J. Med. Food 2013, 16, 259-262. [CrossRef]

51. Hameed, I.; Masoodi, S.R.; Mir, S.A.; Nabi, M.; Ghazanfar, K.; Ganai, B.A. Type 2 diabetes mellitus: From a metabolic disorder to an inflammatory condition. World J. Diabetes 2015, 6, 598-612. [CrossRef] [PubMed]

52. Lin, C.L.; Lin, J.K. Epigallocatechin gallate (EGCG) attenuates high glucose-induced insulin signaling blockade in human hepG2 hepatoma cells. Mol. Nutr. Food Res. 2008, 52, 930-939. [CrossRef] [PubMed]

53. Qin, B.L.; Polansky, M.M.; Harry, D.; Anderson, R.A. Green tea polyphenols improve cardiac muscle mRNA and protein levels of signal pathways related to insulin and lipid metabolism and inflammation in insulin-resistant rats. Mol. Nutr. Food Res. 2010, 54, S14-S23. [CrossRef] [PubMed]

54. Nishikawa, T.; Kukidome, D.; Sonoda, K.; Fujisawa, K.; Matsuhisa, T.; Motoshima, H.; Matsumura, T.; Araki, E. Impact of mitochondrial ROS production in the pathogenesis of insulin resistance. Diabetes Res. Clin. Pract. 2007, 77, S161-S164. [CrossRef] [PubMed]

55. Yasui, K.; Tanabe, H.; Okada, N.; Fukutomi, R.; Ishigami, Y.; Isemura, M. Effects of catechin-rich green tea on gene expression of gluconeogenic enzymes in rat hepatoma H4IIE cells. Biomed. Res. 2010, 31, 183-189. [CrossRef] [PubMed]

56. Shin, D.W.; Kim, S.N.; Lee, S.M.; Lee, W.; Song, M.J.; Park, S.M.; Lee, T.R.; Baik, J.-H.; Kim, H.K.; Hong, J.-H.; et al. (-)-Catechin promotes adipocyte differentiation in human bone marrow mesenchymal stem cells through PPAR $\gamma$ transactivation. Biochem. Pharmacol. 2009, 77, 125-133. [CrossRef] [PubMed]

57. Huang, S.M.; Chang, Y.H.; Chao, Y.C.; Lin, J.A.; Wu, C.H.; Lai, C.Y.; Chan, K.C.; Tseng, S.T.; Yen, G.C. EGCG-rich green tea extract stimulates sRAGE secretion to inhibit S100A12-RAGE axis through ADAM10-mediated ectodomain shedding of extracellular RAGE in type 2 diabetes. Mol. Nutr. Food Res. 2013, 57, 2264-2268. [CrossRef] 
58. Neyestani, T.R.; Shariatzade, N.; Kalayi, A.; Gharavi, A.; Khalaji, N.; Dadkhah, M.; Zowghi, T.; Haidari, H.; Shab-Bidar, S. Regular daily intake of black tea improves oxidative stress biomarkers and decreases serum C-reactive protein levels in type 2 diabetic patients. Ann. Nutr. Metab. 2010, 57, 40-49. [CrossRef]

59. Yamashita, Y.; Wang, L.Q.; Wang, L.H.; Tanaka, Y.; Zhang, T.S.; Ashida, H. Oolong, black and pu-erh tea suppresses adiposity in mice via activation of AMP-activated protein kinase. Food Funct. 2014, 5, 2420-2429. [CrossRef]

60. Hilal, Y.; Engelhardt, U. Correction/Erratum characterisation of white tea-comparison to green and black tea. J. Verbrauch. Lebensm. 2009, 4, 218-220.

61. Sanlier, N.; Atik, İ.; Atik, A. A minireview of effects of white tea consumption on diseases. Trends Food Sci. Technol. 2018, 82, 82-88. [CrossRef]

62. Islam, M.S. Effects of the aqueous extract of white tea (Camellia sinensis) in a streptozotocin-induced diabetes model of rats. Phytomedicine 2011, 19, 25-31. [CrossRef] [PubMed]

63. Xu, N.; Chu, J.; Wang, M.; Chen, L.; Zhang, L.; Xie, Z.W.; Zhang, J.S.; Ho, C.T.; Li, D.X.; Wan, X.C. Large yellow tea attenuates macrophage-related chronic inflammation and metabolic syndrome in high-fat diet treated mice. J. Agric. Food Chem. 2018, 66, 3823-3832. [CrossRef] [PubMed]

64. Yamauchi, R.; Kobayashi, M.; Matsuda, Y.; Ojika, M.; Shigeoka, S.; Yamamoto, Y.; Tou, Y.; Inoue, T.; Katagiri, T.; Murai, A.; et al. Coffee and caffeine ameliorate hyperglycemia, fatty liver, and inflammatory adipocytokine expression in spontaneously diabetic KK-A ${ }^{y}$ Mice. J. Agric. Food Chem. 2010, 58, 5597-5603. [CrossRef] [PubMed]

65. Liu, S.Y.; Yu, Z.; Zhu, H.K.; Zhang, W.; Chen, Y.Q. In vitro $\alpha$-glucosidase inhibitory activity of isolated fractions from water extract of qingzhuan dark tea. BMC Complement. Altern. Med. 2016, 16, 378. [CrossRef] [PubMed]

66. Deng, Y.-T.; Lin-Shiau, S.-Y.; Shyur, L.-F.; Lin, J.-K. Pu-erh tea polysaccharides decrease blood sugar by inhibition of $\alpha$-glucosidase activity in vitro and in mice. Food Funct. 2015, 6, 1539-1546. [CrossRef] [PubMed]

67. Ding, Q.Z.; Zheng, W.; Zhang, B.W.; Chen, X.J.; Zhang, J.; Pang, X.; Zhang, Y.; Jia, D.X.; Pei, S.R.; Dong, Y.S.; et al. Comparison of hypoglycemic effects of ripened pu-erh tea and raw pu-erh tea in streptozotocin-induced diabetic rats. RSC Adv. 2019, 9, 2967-2977. [CrossRef]

68. Lin, H.-C.; Lee, C.-T.; Yen, Y.-Y.; Chu, C.-L.; Hsieh, Y.-P.; Yang, C.-S.; Lan, S.-J. Systematic review and meta-analysis of anti-hyperglycaemic effects of pu-erh tea. Int. J. Food Sci. Technol. 2019, 54, 516-525. [CrossRef]

69. Du, H.; Wang, Q.; Yang, X. Fu Brick Tea alleviates chronic kidney disease of rats with high fat diet consumption through attenuating insulin resistance in skeletal muscle. J. Agric. Food Chem. 2019, 67, 2839-2847. [CrossRef]

70. Renno, W.M.; Abdeen, S.; Alkhalaf, M.; Asfar, S. Effect of green tea on kidney tubules of diabetic rats. Br. J. Nutr. 2008, 100, 652-659. [CrossRef]

71. Zhou, J.; Zhang, L.; Meng, Q.L.; Wang, Y.J.; Long, P.P.; Ho, C.T.; Cui, C.J.; Cao, L.T.; Li, D.X.; Wan, X.C. Roasting improves the hypoglycemic effects of a large-leaf yellow tea infusion by enhancing the levels of epimerized catechins that inhibit $\alpha$-glucosidase. Food Funct. 2018, 9, 5162-5168. [CrossRef] [PubMed]

72. Navarro-Gonzalez, J.F.; Mora-Fernandez, C.; Muros de Fuentes, M.; Garcia-Perez, J. Inflammatory molecules and pathways in the pathogenesis of diabetic nephropathy. Nat. Rev. Nephrol. 2011, 7, 327-340. [CrossRef] [PubMed]

73. Yan, S.J.; Wang, L.; Li, Z.; Zhu, D.N.; Guo, S.C.; Xin, W.F.; Yang, Y.F.; Cong, X.; Ma, T.; Shen, P.P.; et al. Inhibition of advanced glycation end product formation by pu-erh tea ameliorates progression of experimental diabetic nephropathy. J. Agric. Food Chem. 2012, 60, 4102-4110. [CrossRef] [PubMed]

74. Hase, M.; Babazono, T.; Karibe, S.; Kinae, N.; Iwamoto, Y. Renoprotective effects of tea catechin in streptozotocin-induced diabetic rats. Int. Urol. Nephrol. 2006, 38, 693-699. [CrossRef] [PubMed]

75. Yaribeygi, H.; Atkin, S.L.; Sahebkar, A. Interleukin-18 and diabetic nephropathy: A review. J. Cell. Physiol. 2019, 234, 5674-5682. [CrossRef] [PubMed]

76. Jeong, B.C.; Kim, B.S.; Kim, J.I.; Kim, H.H. Effects of green tea on urinary stone formation: An in vivo and in vitro study. J. Endourol. 2006, 20, 356-361. [CrossRef]

77. Fiorino, P.; Evangelista, F.S.; Santos, F; Magri, F.M.M.; Delorenzi, J.C.M.O.B.; Ginoza, M.; Farah, V. The effects of green tea consumption on cardiometabolic alterations induced by experimental diabetes. Exp. Diabetes Res. 2012, 2012, 309231. [CrossRef] 
78. Peixoto, E.B.; Papadimitriou, A.; Teixeira, D.A.T.; Montemurro, C.; Duarte, D.A.; Silva, K.C.; Joazeiro, P.P.; de Faria, J.M.L.; de Faria, J.B.L. Reduced LRP6 expression and increase in the interaction of GSK3 $\beta$ with p53 contribute to podocyte apoptosis in diabetes mellitus and are prevented by green tea. J. Nutr. Biochem. 2015, 26, 416-430. [CrossRef]

79. Yokozawa, T.; Nakagawa, T.; Oya, T.; Okubo, T.; Juneja, L.R. Green tea polyphenols and dietary fibre protect against kidney damage in rats with diabetic nephropathy. J. Pharm. Pharmacol. 2005, 57, 773-780. [CrossRef]

80. Zhu, D.N.; Wang, L.; Zhou, Q.L.; Yan, S.J.; Li, Z.; Sheng, J.; Zhang, W.S. (+)-Catechin ameliorates diabetic nephropathy by trapping methylglyoxal in type 2 diabetic mice. Mol. Nutr. Food. Res. 2014, 58, 2249-2260. [CrossRef]

81. Choi, J.H.; Chai, Y.M.; Joo, G.J.; Rhee, I.K.; Lee, I.S.; Kim, K.R.; Choi, M.S.; Rhee, S.J. Effects of green tea catechin on polymorphonuclear leukocyte 5'-lipoxygenase activity, leukotriene B-4 synthesis, and renal damage in diabetic rats. Ann. Nutr. Metab. 2004, 48, 151-155. [CrossRef] [PubMed]

82. Mohabbulla Mohib, M.; Fazla Rabby, S.M.; Paran, T.Z.; Mehedee Hasan, M.; Ahmed, I.; Hasan, N.; Abu Taher Sagor, M.; Mohiuddin, S.; Hsu, T.-C. Protective role of green tea on diabetic nephropathy-A review. Cogent Biol. 2016, 2, 1248166. [CrossRef]

83. Petroski, M.D.; Deshaies, R. Effects of green tea on matrix metalloproteinases in streptozotocin-induced diabetic rats. J. Clin. Biochem. Nutr. 2005, 37, 77-85.

84. Nagase, H.; Visse, R.; Murphy, G. Structure and function of matrix metalloproteinases and TIMPs. Cardiovasc. Res. 2006, 69, 562-573. [CrossRef] [PubMed]

85. Sarkar, J.; Nandy, S.K.; Chowdhury, A.; Chakraborti, T.; Chakraborti, S. Inhibition of MMP-9 by green tea catechins and prediction of their interaction by molecular docking analysis. Biomed. Pharmacother. 2016, 84, 340-347. [CrossRef] [PubMed]

86. Deng, X.M.; Sun, L.L.; Lai, X.F.; Xiang, L.M.; Li, Q.H.; Zhang, W.J.; Zhang, L.Z.; Sun, S.L. Tea polypeptide ameliorates diabetic nephropathy through RAGE and NF- $\mathrm{kB}$ signaling pathway in type 2 diabetes mice. J. Agric. Food Chem. 2018, 66, 11957-11967. [CrossRef] [PubMed]

87. Ni, D.; Chen, Y.; Song, C.; Xie, B.; Zhou, S. Effect of oolong tea polysaccharide on hepatic-nephritic antioxidation and histommorphology in the diabetic rats. J. Tea Sci. 2003, 23, 11-15.

88. Alves, M.G.; Martins, A.D.; Teixeira, N.F.; Rato, L.; Oliveira, P.F.; Silva, B.M. White tea consumption improves cardiac glycolytic and oxidative profile of prediabetic rats. J. Funct. Foods 2015, 14, 102-110. [CrossRef]

89. Lin, C.; Zhang, M.; Zhang, Y.; Yang, K.; Hu, J.; Si, R.; Zhang, G.; Gao, B.; Li, X.; Xu, C.; et al. Helix B surface peptide attenuates diabetic cardiomyopathy via AMPK-dependent autophagy. Biochem. Biophys. Res. Commun. 2017, 482, 665-671. [CrossRef]

90. Zhou, H.; Chen, Y.; Huang, S.W.; Hu, P.F.; Tang, L.J. Regulation of autophagy by tea polyphenols in diabetic cardiomyopathy. J. Zhejiang Univ.-Sci. B 2018, 19, 333-341. [CrossRef]

91. Fahie, K.; Zachara, N.E. Molecular functions of glycoconjugates in autophagy. J. Mol. Biol. 2016, 428, 3305-3324. [CrossRef] [PubMed]

92. Trivedi, P.C.; Bartlett, J.J.; Perez, L.J.; Brunt, K.R.; Legare, J.F.; Hassan, A.; Kienesberger, P.C.; Pulinilkunnil, T. Glucolipotoxicity diminishes cardiomyocyte TFEB and inhibits lysosomal autophagy during obesity and diabetes. Biochim. Biophys. Acta Mol. Cell Biol. Lipids 2016, 1861, 1893-1910. [CrossRef] [PubMed]

93. Velazquez, A.P.; Graef, M. Autophagy regulation depends on ER homeostasis controlled by lipid droplets. Autophagy 2016, 12, 1409-1410. [CrossRef] [PubMed]

94. Babu, P.V.A.; Sabitha, K.E.; Shyamaladevi, C.S. Green tea impedes dyslipidemia, lipid peroxidation, protein glycation and ameliorates $\mathrm{Ca}^{2+}$-ATPase and $\mathrm{Na}^{+} / \mathrm{K}^{+}$-ATPase activity in the heart of streptozotocin-diabetic rats. Chem.-Biol. Interact. 2006, 162, 157-164. [CrossRef] [PubMed]

95. Potenza, M.A.; Marasciulo, F.L.; Tarquinio, M.; Tiravanti, E.; Colantuono, G.; Federici, A.; Kim, J.A.; Quon, M.J.; Montagnani, M. EGCG, a green tea polyphenol, improves endothelial function and insulin sensitivity, reduces blood pressure, and protects against myocardial I/R injury in SHR. Am. J. Physiol.-Endocrinol. Metab. 2007, 292, E1378-E1387. [CrossRef]

96. Mahmoud, M.F.; Hassan, N.A.; El Bassossy, H.M.; Fahmy, A. Quercetin protects against diabetes-induced exaggerated vasoconstriction in rats: Effect on low grade inflammation. PLoS ONE 2013, 8, e63784. [CrossRef] [PubMed]

97. Braicu, C.; Ladomery, M.R.; Chedea, V.S.; Irimie, A.; Berindan-Neagoe, I. The relationship between the structure and biological actions of green tea catechins. Food Chem. 2013, 141, 3282-3289. [CrossRef] 
98. Babu, P.V.A.; Sabitha, K.E.; Shyamaladevi, C.S. Therapeutic effect of green tea extract on advanced glycation and cross-linking of collagen in the aorta of streptozotocin diabetic rats. Clin. Exp. Pharmacol. Physiol. 2006, 33, 351-357. [CrossRef]

99. Minatti, J.; Wazlawik, E.; Hort, M.A.; Zaleski, F.L.; Ribeiro-do-Valle, R.M.; Maraschin, M.; da Silva, E.L. Green tea extract reverses endothelial dysfunction and reduces atherosclerosis progression in homozygous knockout low-density lipoprotein receptor mice. Nutr. Res. 2012, 32, 684-693. [CrossRef]

100. Babu, P.V.A.; Sabitha, K.E.; Srinivasan, P.; Shyamaladevi, C.S. Green tea attenuates diabetes induced Maillard-type fluorescence and collagen cross-linking in the heart of streptozotocin diabetic rats. Pharmacol. Res. 2007, 55, 433-440. [CrossRef]

101. Tijburg, L.M.B.; Mattern, T.; Folts, J.D.; Weisgerber, U.M.; Katan, M.B. Tea flavonoids and cardiovascular diseases: A review. Crit. Rev. Food Sci. Nutr. 1997, 37, 771-785. [CrossRef] [PubMed]

102. Murase, T.; Misawa, K.; Haramizu, S.; Hase, T. Catechin-induced activation of the LKB1/AMP-activated protein kinase pathway. Biochem. Pharmacol. 2009, 78, 78-84. [CrossRef]

103. Zhao, P.; Kuai, J.K.; Gao, J.J.; Sun, L.; Wang, Y.; Yao, L.N. Delta opioid receptor agonist attenuates lipopolysaccharide-induced myocardial injury by regulating autophagy. Biochem. Biophys. Res. Commun. 2017, 492, 140-146. [CrossRef] [PubMed]

104. Yaribeygi, H.; Atkin, S.L.; Pirro, M.; Sahebkar, A. A review of the anti-inflammatory properties of antidiabetic agents providing protective effects against vascular complications in diabetes. J. Cell. Physiol. 2019, 234, 8286-8294. [CrossRef] [PubMed]

105. Anter, E.; Chen, K.; Shapira, O.M.; Karas, R.H.; Keaney, J.F. P38 Mitogen-activated protein kinase activates eNOS in endothelial cells by an estrogen receptor $\alpha$-dependent pathway in response to black tea polyphenols. Circ. Res. 2005, 96, 1072-1078. [CrossRef] [PubMed]

106. Anter, E.; Thomas, S.R.; Schulz, E.; Shapira, O.M.; Vita, J.A.; Keaney, J.F. Activation of endothelial nitric-oxide synthase by the p38 MAPK in response to black tea polyphenols. J. Biol. Chem. 2004, 279, 46637-46643. [CrossRef] [PubMed]

107. Rahma, A.; Martini, R.; Kusharto, C.M.; Damayanthi, E.; Rohdiana, D. White tea camellia sinensis and moringa oleifera as antihyperglycemic agent on streptozotocin-induced diabetic sprague dawley rats. Jurnal Gizi dan Pangan 2017, 12, 179-186. [CrossRef]

108. Bhattacharya, S.; Gachhui, R.; Sil, P.C. Effect of Kombucha, a fermented black tea in attenuating oxidative stress mediated tissue damage in alloxan induced diabetic rats. Food Chem. Toxicol. 2013, 60, 328-340. [CrossRef]

109. Rodrigues, B.; Cam, M.C.; McNeill, J.H. Metabolic disturbances in diabetic cardiomyopathy. Mol. Cell. Biochem. 1998, 180, 53-57. [CrossRef]

110. How, O.J.; Aasum, E.; Severson, D.L.; Chan, W.Y.A.; Essop, M.F.; Larsen, T.S. Increased myocardial oxygen consumption reduces cardiac efficiency in diabetic mice. Diabetes 2006, 55, 466-473. [CrossRef]

111. Xu, J.Y.; Wang, M.; Zhao, J.P.; Wang, Y.H.; Tang, Q.; Khan, I.A. Yellow tea (Camellia sinensis L.), a promising Chinese tea: Processing, chemical constituents and health benefits. Food Res. Int. 2018, 107, 567-577. [CrossRef] [PubMed]

112. Han, M.M.; Zhao, G.S.; Wang, Y.J.; Wang, D.X.; Sun, F.; Ning, J.M.; Wan, X.C.; Zhang, J.S. Safety and anti-hyperglycemic efficacy of various tea types in mice. Sci. Rep. 2016, 6, 31703. [CrossRef] [PubMed]

113. Zhu, Q.Y.; Hackman, R.M.; Ensunsa, J.L.; Holt, R.R.; Keen, C.L. Antioxidative activities of oolong tea. J. Agric. Food Chem. 2002, 50, 6929-6934. [CrossRef] [PubMed]

114. Cai, X.B.; Hayashi, S.; Fang, C.Y.; Hao, S.M.; Wang, X.J.; Nishiguchi, S.; Tsutsui, H.; Sheng, J. Pu-erh tea extract-mediated protection against hepatosteatosis and insulin resistance in mice with diet-induced obesity is associated with the induction of de novo lipogenesis in visceral adipose tissue. J. Gastroenterol. 2017, 52, 1240-1251. [CrossRef] [PubMed]

115. Shammas, M.A.; Neri, P.; Koley, H.; Batchu, R.B.; Bertheau, R.C.; Munshi, V.; Prabhala, R.; Fulciniti, M.; Tai, Y.; Treon, S.P.; et al. Specific killing of multiple myeloma cells by (-)-epigaflocatechin-3-gallate extracted from green tea: Biologic activity and therapeutic implications. Blood 2006, 108, 2804-2810. [CrossRef] [PubMed]

116. Lee, H.; Bae, J.H.; Lee, S.R. Protective effect of green tea polyphenol EGCG against neuronal damage and brain edema after unilateral cerebral ischemia in gerbils. J. Neurosci. Res. 2004, 77, 892-900. [CrossRef] [PubMed] 
117. Singal, A.; Anjaneyulu, M.; Chopra, K. Modulatory role of green tea extract on antinociceptive effect of morphine in diabetic mice. J. Med. Food 2005, 8, 386-391. [CrossRef] [PubMed]

118. Zhong, J.X.; Xu, C.; Reece, E.A.; Yang, P.X. The green tea polyphenol EGCG alleviates maternal diabetes-induced neural tube defects by inhibiting DNA hypermethylation. Am. J. Obstet. Gynecol. 2016, 215, 368. [CrossRef] [PubMed]

119. Barber, A.J. A new view of diabetic retinopathy: A neurodegenerative disease of the eye. Prog. NeuroPsychopharmacol. Biol. Psychiatry 2003, 27, 283-290. [CrossRef]

120. Rahimi-Madiseh, M.; Malekpour-Tehrani, A.; Bahmani, M.; Rafieian-Kopaei, M. The research and development on the antioxidants in prevention of diabetic complications. Asian Pac. J. Trop. Med. 2016, 9, 825-831. [CrossRef]

121. Mustata, G.T.; Rosca, M.; Biemel, K.M.; Reihl, O.; Smith, M.A.; Viswanathan, A.; Strauch, C.; Du, Y.; Tang, J.; Kern, T.S.; et al. Paradoxical effects of green tea (Camellia Sinensis) and antioxidant vitamins in diabetic rats: Improved retinopathy and renal mitochondrial defects but deterioration of collagen matrix glycoxidation and cross-linking. Diabetes 2005, 54, 517-526. [CrossRef] [PubMed]

122. Silva, K.C.; Rosales, M.A.B.; Hamassaki, D.E.; Saito, K.C.; Faria, A.M.; Ribeiro, P.A.O.; de Faria, J.B.L.; de Faria, J.M.L. Green tea is neuroprotective in diabetic retinopathy. Investig. Ophthalmol. Vis. Sci. 2013, 54, 1325-1336. [CrossRef] [PubMed]

123. Kumar, B.; Gupta, S.K.; Nag, T.C.; Srivastava, S.; Saxena, R. Green tea prevents hyperglycemia-induced retinal oxidative stress and inflammation in streptozotocin-induced diabetic rats. Ophthalmic Res. 2012, 47, 103-108. [CrossRef] [PubMed]

124. Vinson, J.A.; Zhang, J. Black and green teas equally inhibit diabetic cataracts in a streptozotocin-induced rat model of diabetes. J. Agric. Food Chem. 2005, 53, 3710-3713. [CrossRef]

125. Sook, S.J.; Quan, Z.-J. Effect of oolong tea extracts on plasma glucose level and antioxidant system in diabetic rats. J. Community Nutr. 2006, 8, 208-214.

126. Al-Hussaini, A.A.; Sulaiman, N.M.; AlZahrani, M.D.; Alenizi, A.S.; Khan, M. Prevalence of hepatopathy in type 1 diabetic children. BMC Pediatr. 2012, 12, 160. [CrossRef] [PubMed]

127. Akbar, A.A.; Daryoush, M.; Ali, R.; Mehrdad, N. Green tea attenuates hepatic tissue injury in STZ-streptozotocin-induced diabetic rats. J. Anim. Vet. Adv. 2012, 11, 2081-2090. [CrossRef]

128. Xiao, J.; Lu, R.; Shen, X.; Wu, M. Green tea extracts protected against carbon tetrachloride-induced chronic liver damage and cirrhosis. Chin. J. Prev. Med. 2002, 36, 243-246.

129. Li, Y.-M.; Zhang, X.-G.; Zhou, H.-L.; Chen, S.-H.; Zhang, Y.; Yu, C.-H. Effects of tea polyphenols on hepatic fibrosis in rats with alcoholic liver disease. Hepatobil. Pancreat. Dis. Int. 2004, 3, 577-579.

130. Thomson, M.; Al-Qattan, K.; Mansour, M.H.; Ali, A. Green tea attenuates oxidative stress and downregulates the expression of angiotensin $\mathrm{II}_{\mathrm{AT}_{1}}$ receptor in renal and hepatic tissues of streptozotocin-induced diabetic rats. Evid.-Based Complement. Altern. Med. 2012, 2012, 409047. [CrossRef]

131. Gennaro, G.; Claudino, M.; Cestari, T.M.; Ceolin, D.; Germino, P.; Garlet, G.P.; de Assis, G.F. Green tea modulates cytokine expression in the periodontium and attenuates alveolar bone resorption in type 1 diabetic rats. PLoS ONE 2015, 10, e0134784. [CrossRef] [PubMed]

132. Ko, C.H.; Lau, K.M.; Choy, W.Y.; Leung, P.C. Effects of tea catechins, epigallocatechin, gallocatechin, and gallocatechin gallate, on bone metabolism. J. Agric. Food Chem. 2009, 57, 7293-7297. [CrossRef] [PubMed]

133. Li, J.; Shen, X.P. Effect of rosiglitazone on inflammatory cytokines and oxidative stress after intensive insulin therapy in patients with newly diagnosed type 2 diabetes. Diabetol. Metab. Syndr. 2019, 11, 35. [CrossRef] [PubMed]

134. Satoh, T.; Igarashi, M.; Yamada, S.; Takahashi, N.; Watanabe, K. Inhibitory effect of black tea and its combination with acarbose on small intestinal $\alpha$-glucosidase activity. J. Ethnopharmacol. 2015, 161, 147-155. [CrossRef] [PubMed]

135. Gao, J.J.; Xu, P.; Wang, Y.F.; Wang, Y.Q.; Hochstetter, D. Combined Effects of Green Tea Extracts, Green Tea Polyphenols or Epigallocatechin Gallate with Acarbose on Inhibition against $\alpha$-Amylase and alpha-Glucosidase in Vitro. Molecules 2013, 18, 11614-11623. [CrossRef]

136. Huang, H.; Jin, C.Y.; Bi, X.K.; Zhao, Y.B.; Xu, S.J.; Wang, M.H.; Yu, L.; Sun, Y.X.; Hu, D. Green tea polyphenol epigallocatechin-3-gallate promotes reendothelialization in carotid artery of diabetic rabbits by reactivating Akt/eNOS pathway. Front. Pharmacol. 2018, 9. [CrossRef] [PubMed] 
137. Chen, T.S.; Liou, S.Y.; Kuo, C.H.; Pan, L.F.; Yeh, Y.L.; Liou, J.; Padma, V.V.; Yao, C.H.; Kuo, W.W.; Huang, C.Y. Green tea epigallocatechin gallate enhances cardiac function restoration through survival signaling expression in diabetes mellitus rats with autologous adipose tissue-derived stem cells. J. Appl. Physiol. 2017, 123, 1081-1091. [CrossRef]

138. Itoh, T.; Imano, M.; Nishida, S.; Tsubaki, M.; Hashimoto, S.; Ito, A.; Satou, T. (-)-Epigallocatechin-3-gallate protects against neuronal cell death and improves cerebral eunction after traumatic brain injury in rats. Neuromol. Med. 2011, 13, 300-309. [CrossRef]

139. Tian, C.; Ye, X.L.; Zhang, R.; Long, J.; Ren, W.Y.; Ding, S.B.; Liao, D.; Jin, X.; Wu, H.M.; Xu, S.Q.; et al. Green tea polyphenols reduced fat deposits in high fat-fed rats via erk1/2-PPAR gamma-adiponectin pathway. PLOS ONE 2013, 8, e53796. [CrossRef]

140. Babu, P.V.A.; Sabitha, K.E.; Shyamaladevi, C.S. Green tea extract impedes dyslipidaemia and development of cardiac dysfunction in streptozotocin-diabetic rats. Clin. Exp. Pharmacol. Physiol. 2006, 33, 1184-1189. [CrossRef]

141. Abolfathi, A.A.; Mohajeri, D.; Rezaie, A.; Nazeri, M. Protective effects of green tea extract against hepatic tissue injury in streptozotocin-induced diabetic rats. Evid.-Based Complement. Altern. Med. 2012, 2012, 740671. [CrossRef] [PubMed]

142. Renno, W.M.; Alkhalaf, M.; Afsari, Z.; Abd-El-Basset, E.; Mousa, A. Consumption of green tea alters glial fibriliary acidic protein immunoreactivity in the spinal cord astrocytes of STZ-diabetic rats. Nutr. Neurosci. 2008, 11, 32-40. [CrossRef] [PubMed]

143. Manikandan, R.; Sundaram, R.; Thiagarajan, R.; Sivakumar, M.R.; Meiyalagan, V.; Arumugam, M. Effect of black tea on histological and immunohistochemical changes in pancreatic tissues of normal and streptozotocin-induced diabetic mice (Mus musculus). Microsc. Res. Tech. 2009, 72, 723-726. [CrossRef] [PubMed]

144. Kumar, D.; Rizvi, S.I. Black tea extract improves anti-oxidant profile in experimental diabetic rats. Arch. Physiol. Biochem. 2015, 121, 109-115. [CrossRef] [PubMed]

145. Tenore, G.C.; Stiuso, P.; Campiglia, P.; Novellino, E. In vitro hypoglycaemic and hypolipidemic potential of white tea polyphenols. Food Chem. 2013, 141, 2379-2384. [CrossRef] [PubMed]

146. Dias, T.R.; Alves, M.G.; Rato, L.; Casal, S.; Silva, B.M.; Oliveira, P.F. White tea intake prevents prediabetes-induced metabolic dysfunctions in testis and epididymis preserving sperm quality. J. Nutr. Biochem. 2016, 37, 83-93. [CrossRef] [PubMed]

147. Huang, Q.F.; Chen, S.H.; Chen, H.; Wang, Y.F.; Wang, Y.Q.; Hochstetter, D.; Xu, P. Studies on the bioactivity of aqueous extract of pu-erh tea and its fractions: In vitro antioxidant activity and alpha-glycosidase inhibitory property, and their effect on postprandial hyperglycemia in diabetic mice. Food Chem. Toxicol. 2013, 53, 75-83. [CrossRef]

148. Xu, P.; Chen, H.; Wang, Y.Q.; Hochstetter, D.; Zhou, T.; Wang, Y.F. Oral administration of pu-erh tea polysaccharides lowers blood glucose levels and enhances antioxidant status in alloxan-induced diabetic mice. J. Food Sci. 2012, 77, H246-H252. [CrossRef]

149. Yuqiong, C.; Zhi, Y.U.; Yun, Z.; Dejiang, N.I.; Bijun, X.I.E.; Jirong, Z. Influence of oolong tea polysaccharides on immunomodulatory function of diabetic mice and rats. Acta Nutr. Sin. 2006, 28, 156-159.

150. Song, E.K.; Hur, H.; Han, M.K. Epigallocatechin gallate prevents autoimmune diabetes induced by multiple low doses of streptozotocin in mice. Arch. Pharm. Res. 2003, 26, 559-563. [CrossRef]

151. Rhee, S.J.; Kim, M.J.; Kwag, O.G. Effects of green tea catechin on prostaglandin synthesis of renal glomerular and renal dysfunction in streptozotocin-induced diabetic rats. Asia Pac. J. Clin. Nutr. 2002, 11, 232-236. [CrossRef] [PubMed]

152. Rhee, S.J.; Choi, J.H.; Park, M.R. Green tea catechin improves microsomal phospholipase $\mathrm{A}_{2}$ activity and the arachidonic acid cascade system in the kidney of diabetic rats. Asia Pac. J. Clin. Nutr. 2002, 11, 226-231. [CrossRef] [PubMed]

153. Nogueira de Amorim, L.M.N.; Vaz, S.R.; Cesario, G.; Coelho, A.S.G.; Botelho, P.B. Effect of green tea extract on bone mass and body composition in individuals with diabetes. J. Funct. Foods 2018, 40, 589-594. [CrossRef]

154. Mirzaei, K.; Hossein-Nezhad, A.; Karimi, M.; Hosseinzadeh-Attar, M.J.; Jafari, N.; Najmafshar, A.; Larijani, B. Effect of green tea extract on bone turnover markers in type 2 diabetic patients; a double-blind, placebo-controlled clinical trial study. DARU J. Pharm. Sci. 2009, 17, 38-44. 
155. Mousavi, A.; Vafa, M.; Neyestani, T.; Khamseh, M.; Hoseini, F. The effects of green tea consumption on metabolic and anthropometric indices in patients with Type 2 diabetes. J. Res. Med. Sci. 2013, 18, 1080-1086. [PubMed]

156. Liu, C.Y.; Huang, C.J.; Huang, L.H.; Chen, I.J.; Chiu, J.P.; Hsu, C.H. Effects of green tea extract on insulin resistance and glucagon-like peptide 1 in patients with type 2 diabetes and lipid abnormalities: A randomized, double-blinded, and placebo-controlled trial. PLoS ONE 2014, 9, e91163. [CrossRef] [PubMed]

157. Hosoda, K.; Wang, M.F.; Liao, M.L.; Chuang, C.K.; Iha, M.; Clevidence, B.; Yamamoto, S. Antihyperglycentic effect of oolong tea in type 2 diabetes. Diabetes Care 2003, 26, 1714-1718. [CrossRef] [PubMed]

158. Vaz, S.R.; de Amorim, L.M.N.; de Nascimento, P.V.F.; Veloso, V.S.P.; Nogueira, M.S.; Castro, I.A.; Mota, J.F.; Botelho, P.B. Effects of green tea extract on oxidative stress and renal function in diabetic individuals: A randomized, double-blinded, controlled trial. J. Funct. Foods 2018, 46, 195-201. [CrossRef]

159. MacKenzie, T.; Leary, L.; Brooks, W.B. The effect of an extract of green and black tea on glucose control in adults with type 2 diabetes mellitus: Double-blind randomized study. Metabolism 2007, 56, 1340-1344. [CrossRef]

(C) 2019 by the authors. Licensee MDPI, Basel, Switzerland. This article is an open access article distributed under the terms and conditions of the Creative Commons Attribution (CC BY) license (http://creativecommons.org/licenses/by/4.0/). 